\title{
Toward the synthesis of fine chemicals from lactose: preparation of D-xylo and L- lyxo-aldohexos-5-ulose derivatives ${ }^{\neq}$
}

\author{
Giorgio Catelani, ${ }^{\mathrm{a}, *}$ Felicia D’Andrea, ${ }^{\mathrm{a}}$ Lorenzo Guazzelli, ${ }^{\mathrm{a}}$ Venerando Pistarà ${ }^{\mathrm{b}}$ \\ ${ }^{a}$ Dipartimento di Chimica Bioorganica e Biofarmacia, Università di Pisa, Via Bonanno, 33 I-56126, Pisa, Italy \\ ${ }^{b}$ Dipartimento di Scienze Chimiche, Università di Catania, viale A. Doria, 6 I-95125, Catania, Italy
}

\begin{abstract}
The transformation of $(5 R)$-2,6-di- $O$-benzyl-5- $C$-methoxy- $\beta$-D-galactopyranosyl-( $1 \rightarrow 4)$-2,3:5,6-di- $O$ isopropylidene-aldehydo-D-glucose dimethyl acetal (8) into partially protected derivatives of D-xylo- and L-lyxoaldohexos-5-ulose has been reported, applying appropriate epimerization methods to its $3^{\prime}-O$ - and 4'-O-protected alcoholic derivatives.
\end{abstract}

Keywords: Lactose, D-xylo-Aldohexos-5-ulose, L-lyxo-Aldohexos-5-ulose, 1,5-Bis-glycopyranosides, Epimerization

\section{Introduction}

Lactose is the most abundant natural reducing disaccharide, obtained from whey, a by-product of the agro-industrial cheese production. Although its large worldwide availability, estimated in about 500,000 tons/year, ${ }^{2 a}$ only a low percentage of recovered lactose is utilized, mainly in the food, feed and pharmaceutical fields. The chemical valorisation of lactose is achieved through simple transformations into commercially available products as lactobionic acid, ${ }^{2}$ a component of the preservative solution for transplanting organs, lactitol, ${ }^{2}$ a suitable component of sugar-free, reduced calories and low glycaemic products, and lactulose and galacto-oligosaccharides (GOS), ${ }^{2}$ largely used in probiotic therapy.

Since lactose is cheap and there is a potential environmental risk connected with the uncontrolled dispersion of whey in freshwater, new synthetic channels are investigated in order to synthesise fine chemicals starting from this renewable raw material.

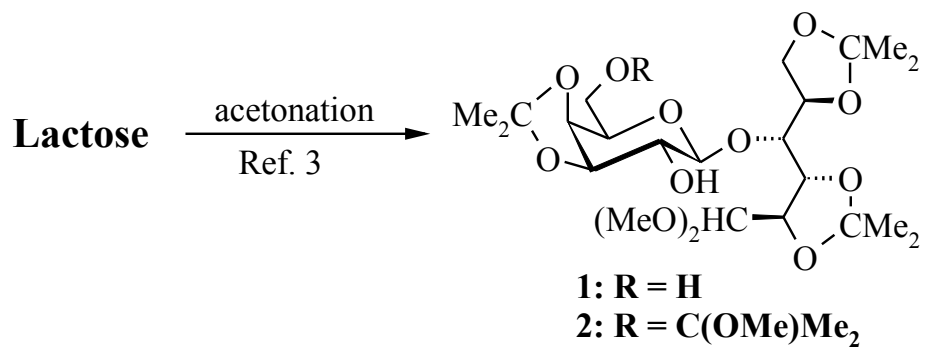

Figure 1. Polyacetonides directly obtained by acetonation of lactose

\footnotetext{
"Fart 26 of the series "Chemical Valorisation of Milk-derived Carbohydrates". For part 25 see Ref. 1.

*Corresponding author. Tel: +390502219700; fax: +390502219660; e-mail: giocate@farm.unipi.it
} 
Recently, we have planned a synthetic strategy to elaborate the not reducing unit and not to modify the reducing one, as commonly done. This useful approach takes advantage of the large availability ${ }^{3}$ of the two polyacetonides $\mathbf{1}$ and $\mathbf{2}$ (Figure 1), which could be considered as simple $\beta$-Dgalactopyranosides, due to the complete protection of the D-glucose unit. Aldohexos-5-uloses (3) represent an interesting, although yet poorly investigated class of dicarbonyl hexoses, ${ }^{4}$ useful synthetic intermediates for the preparation of high added value compounds such as azasugars ${ }^{5}$ and cyclitols, as inositols, ${ }^{6}$ or polyhydroxycyclopentanes. ${ }^{7}$

A general approach (Chart 1) to aldohexos-5-uloses (3) was developed ${ }^{8}$ using as key reaction the epoxidation-methanolysis of hex-4-enopyranosides of type 5, in turn obtained from 3,4-Oisopropylidene- $\beta$-D-galactopyranosides (6).

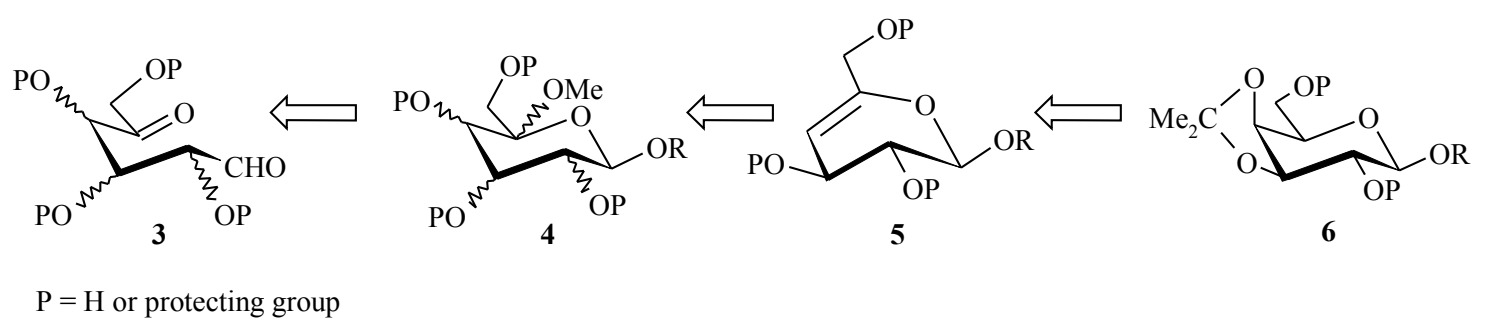

Chart 1. General approach to aldohexos-5-uloses from $\beta$-D-galactopyranosides

In this communication we present the synthesis of partially protected derivatives of D-xylo and Llyxo-aldohexos-5-uloses achieved here from the disaccharide 1',5'-bis-glycoside 8, analogous to 4, in turn easily obtained from lactose, ${ }^{9}$ following the same general approach outlined in Chart 1 . The influence of the axial C-5'-OMe group on the chemo- and the stereoselectivity of some reactions performed on the bis-glycoside unit is also observed and discussed.

\section{Results and Discussion}

Preliminary attempts to obtain 1,5-bis-glycopyranosides of the D-xylo series through epoxidationmethanolysis of a 3'-O-protected derivative of the known disaccharide hex-4'-enopyranoside $7,{ }^{9}$ following the method previously used in monosaccharide series, ${ }^{8 b}$ were abandoned due to the difficulties encountered in the separation of the complex crude diastereoisomeric mixture. It was considered the alternative way based on the regioselective protection of 3 '-OH of the known diol $\mathbf{8},{ }^{9}$ followed by stereoselective epimerization at C-4' (Scheme 1). The first step was easily achieved through the stannylidene acetal-mediated alkylation method, largely used to differentiate 1,2-cisdiols of sugar, ${ }^{10}$ but until now, never reported on a 1,5-bis-glycopyranoside. As in the case of $\beta$-Dgalactopyranosides ${ }^{10}$ the alkylation took place with complete regioselectivity on 3 '-OH leading in almost quantitative yield to the alcohol 9. 

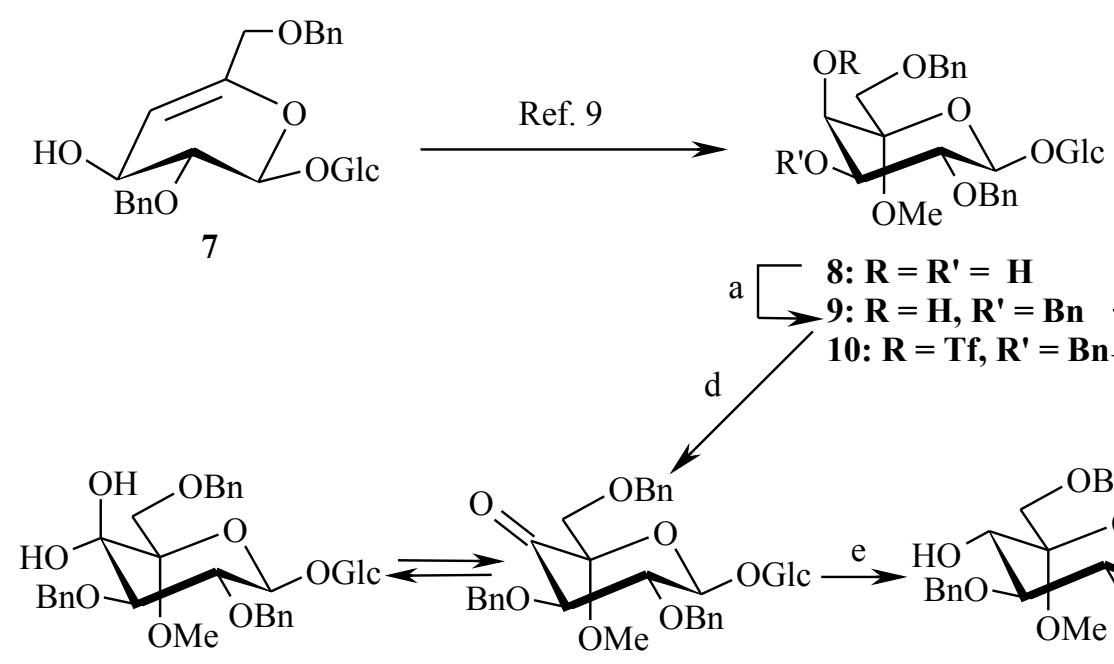

13

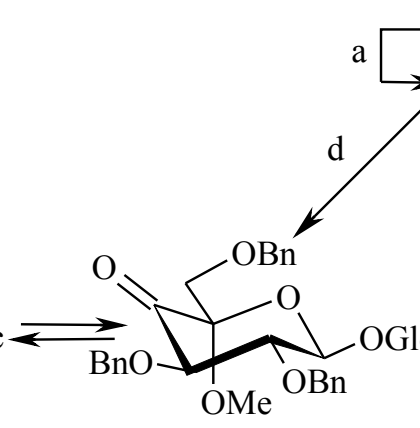

12

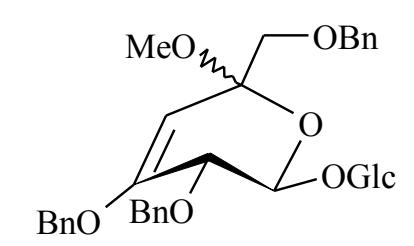

11

$\mathbf{R}=\mathbf{R}^{\prime}=\mathbf{H}$

9: $R=H, R^{\prime}=B n$

10: $\mathbf{R}=\mathbf{T f}, \mathbf{R}^{\prime}=\mathbf{B n} \longleftarrow \underline{\mathrm{b}}$

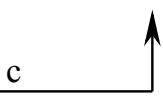

Scheme 1. Stereoselective synthesis of 2,3,6-tri-O-benzyl-D-xylo-hexos-5-ulose. Reagent and conditions: (a) $\mathrm{Bu}_{2} \mathrm{SnO}_{\text {, }}$ $\mathrm{C}_{6} \mathrm{H}_{5} \mathrm{CH}_{3}$, reflux, $12 \mathrm{~h}$, then $\mathrm{BnBr}, \mathrm{Bu}_{4} \mathrm{NBr}$, reflux, $1.5 \mathrm{~h}$ (94\%); (b) $\mathrm{Tf}_{2} \mathrm{O}, 1: 1 \mathrm{CH}_{2} \mathrm{Cl}_{2}-\mathrm{Py}$, room temp, $6 \mathrm{~h}(88 \%)$; (c) $\mathrm{Bu}_{4} \mathrm{NNO}_{2}, \mathrm{C}_{6} \mathrm{H}_{5} \mathrm{CH}_{3}$, reflux, $8 \mathrm{~h}\left(70 \%\right.$ ); (d) TPAP, NMO, $\mathrm{CH}_{2} \mathrm{Cl}_{2}, 4 \AA$, room temp, 4 h; (e) $\mathrm{NaBH}_{4}, \mathrm{MeOH}$, room temp, $1.5 \mathrm{~h},\left(64 \%\right.$ from 9); (f) $90 \%$ aq $\mathrm{CF}_{3} \mathrm{COOH}, 4: 1 \mathrm{CH}_{3} \mathrm{CN}_{-} \mathrm{H}_{2} \mathrm{O}, 50{ }^{\circ} \mathrm{C}, 12 \mathrm{~h}(72 \%)$.

The first C-4' epimerization strategy was attempted via a $S_{N} 2$ displacement on the triflate 10, obtained from 9 in high isolated yield $(88 \%)$ by treatment with $\mathrm{Tf}_{2} \mathrm{O}$ in pyridine. Surprisingly, the treatment of $\mathbf{1 0}$ with $\mathrm{Bu}_{4} \mathrm{NNO}_{2}$ in toluene led to the formation of enol ether 11, isolated in $70 \%$ yield, instead to the desired inverted bis-glycoside 14. This result is quite unexpected in light of the high yields reported for nucleophilic substitutions of structurally related 4-O-triflates of galactopyranosides ${ }^{11}$ and is evidently due to some interference between the axial 5'-OMe group and the nucleophile approaching the vicinal reacting centre. The complementary strategy based on an oxidation-reduction sequence of 9 was thus explored. Also in the oxidation of $\mathbf{9}$, the presence of the axial C-5' methoxyl group sensibly influenced the reaction. Swern oxidation attempts failed completely, while the treatment with PCC showed a low conversion even after long reaction times. Better results were obtained with the TPAP-NMO system, employing however an unexpectedly high catalyst molar ratio (40\%) with respect to that usually needed $(5 \%){ }^{12}$ NMR analysis of the crude oxidation product showed a mixture of the 4 -ulosyl derivative $12\left(\mathrm{C}-4{ }^{13} \mathrm{C}\right.$ chemical shift: $198.3 \mathrm{ppm})$ and of its hydrate 13 (C-4, ${ }^{13} \mathrm{C}$ chemical shift: $\left.97.1 \mathrm{ppm}\right)$. In the crude oxidation mixture, isolated in about 89\%, compounds $\mathbf{1 2}$ and $\mathbf{1 3}$ were present in about 4:1 ratio, as determined on the basis of the relative intensity of the ${ }^{13} \mathrm{C} 5$-OMe signals. Chromatographic purification led again to a mixture of $\mathbf{1 2}$ and $\mathbf{1 3}$ in the same 4:1 ratio, but with substantial loss of product, lowering the yield to a modest $56 \%$. The reduction of the crude oxidation mixture with $\mathrm{NaBH}_{4}$ in $\mathrm{MeOH}$ led to 14 and 9 in 64 and 20\% isolated yield, respectively, indirectly confirming the structures of $\mathbf{1 2}$ and $\mathbf{1 3}$ and the extensive loss of the uloside during the chromatography on silica gel. In the case of the hydride reduction, the presence of the axial 5'-OMe group was beneficial for 
the stereoselectivity, determining the prevalence, although not complete, of attack on the $\beta$ face. This result is at variance with respect to the hydride reduction of analogous 4-keto-D-arabinohexopyranosides, leading mainly to D-galactopyranosides. ${ }^{13}$ Finally the target 2,6-di-O-benzyl-Dxylo-aldohexos-5-ulose (15) was obtained from 14 (72\% yield) by acid hydrolysis with $\mathrm{CF}_{3} \mathrm{COOH}$ in $\mathrm{CH}_{3} \mathrm{CN}$-water $\left(50{ }^{\circ} \mathrm{C}, 12 \mathrm{~h}\right)$ and separation from D-glucose by extraction with EtOAc. As previously reported, ${ }^{8 \mathrm{~b}} \mathbf{1 5}$ was present in $\mathrm{CD}_{3} \mathrm{CN}$ as a 55:45 $\alpha, \beta-1,4$-furanose mixture, as confirmed by NMR analysis.

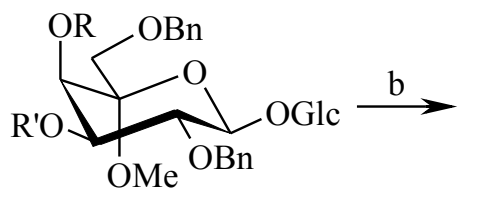

$\mathrm{a} \longrightarrow \mathrm{R}=\mathbf{R}^{\prime}=\mathbf{H}$
$\longrightarrow$ 16: $\mathbf{R}=\mathbf{O A c}, \mathbf{R}^{\prime}=\mathbf{H}$

$\downarrow$

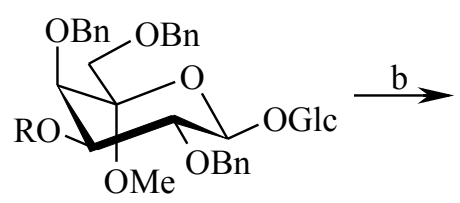

22: $\mathbf{R}=\mathbf{H}$

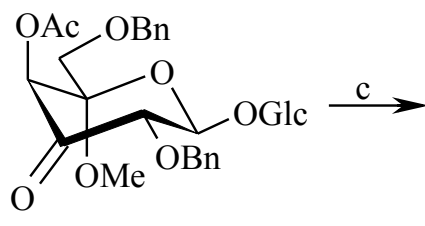

17

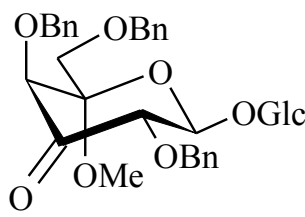

24

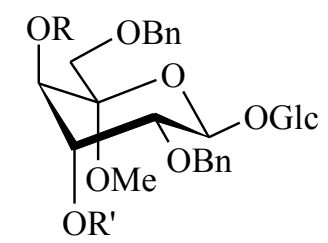

18: $\mathbf{R}=\mathbf{A c}, \mathbf{R}^{\prime}=\mathbf{H}$

19: $R=H, R^{\prime}=A c$

20: $\mathbf{R}=\mathbf{R}^{\prime}=A c$

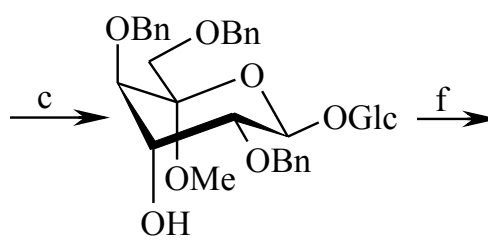

25
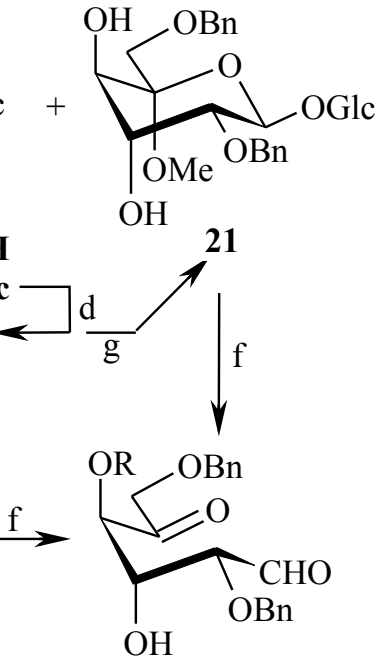

26: $\mathbf{R}=\mathbf{H}$

27: $\mathbf{R}=\mathbf{B n}$

Scheme 2. Synthesis of 2,6-di- $O$-benzyl- and 2,4,6-tri- $O$-benzyl-L-lyxo-aldohexos-5-ulose. Reagents and conditions: (a) $\mathrm{CH}_{3} \mathrm{C}(\mathrm{OEt})_{3}, \mathrm{TsOH}, \mathrm{C}_{6} \mathrm{H}_{5} \mathrm{CH}_{3}, 45^{\circ} \mathrm{C}, 25 \mathrm{~min}$, then $80 \%$ aq AcOH, room temp, 15 min (quantitative); (b) TPAP, $\mathrm{NMO}, \mathrm{CH}_{2} \mathrm{Cl}_{2}, 4 \AA$, room temp, $45 \min \left(17: 98 \%\right.$, 24: 76\%); (c) $\mathrm{NaBH}_{4}, \mathrm{MeOH}$, room temp, $20 \mathrm{~min}$ (25: 88\%); (d) 1:2 $\mathrm{Ac}_{2} \mathrm{O}-\mathrm{Py}$, room temp, $20 \mathrm{~h}$; (e) $\mathrm{NaH}, \mathrm{BnBr}(1 \mathrm{eq})$, DMF, $0{ }^{\circ} \mathrm{C}, 25 \min (\mathbf{2 2}: 75 \%+23: 15 \%)$; (f) $90 \%$ aq $\mathrm{CF}_{3} \mathrm{COOH}_{4} 4: 1$ $\mathrm{CH}_{3} \mathrm{CN}-\mathrm{H}_{2} \mathrm{O}, 50{ }^{\circ} \mathrm{C}, 4 \mathrm{~h}$ (26: 78\%, 27:86\%); (g) 0.1 M MeONa-MeOH, room temp, 2 h (quantitative).

The preparation of L-lyxo derivatives was based on the same approach used in the monosaccharide series, ${ }^{8 c}$ providing an oxidation-reduction sequence of a 3-OH free 1,5-bis-methyl L-arabinohexopyranoside, obtained through the completely regioselective orthoester-mediated 4'-Oacetylation of the diol $\mathbf{8}$ (Scheme 2). As expected, the treatment of $\mathbf{8}$ with $\mathrm{CH}_{3} \mathrm{C}(\mathrm{OEt})_{3}$ and $\mathrm{TsOH}$ in toluene followed by the opening of the orto-acetate ring with $\mathrm{AcOH}$, afforded in almost quantitative yield the alcohol 16. The next oxidation step was achieved again using the TPAP-NMO system under milder reaction conditions with respect to those used before (TPAP 5\%, 2 h, 98\% yield). The reduction of $17\left(\mathrm{NaBH}_{4}, \mathrm{MeOH}\right)$ appeared not as simple as for the analogous 1,5-bis-methylglycopyranoside, for which only the formation of the two 5'-OMe L-lyxo and L-arabino diastereoisomers in a 5:1 ratio was reported. ${ }^{8 c}$ In fact, the reduction of the uloside $\mathbf{1 7}$ led to a complex product mixture, constituted (TLC, 1:1 EtOAc-hexane) of at least four components displaying two well differentiated ranges of $R_{\mathrm{f}}$ values on silica gel. The flash chromatography permitted only a partial separation of the two faster moving components $\left(R_{\mathrm{f}} 0.39\right.$ and 0.34 , 
respectively), surprisingly identified (NMR) as the two isomeric L-lyxo monoacetates $\mathbf{1 8}$ and $\mathbf{1 9}$, accounting for a combined $52 \%$ yield. The structure of the above compounds was further confirmed through conventional acetylation leading, in both cases, to the same diacetate 20. Two other fractions containing the lower moving components $\left(R_{\mathrm{f}} \quad 0.23\right.$ and 0.20$)$ were collected, one constituted by the pure L-lyxo diol 21 (13\% yield) and the other by a mixture (about 1:1, combined yield $26 \%$ ) of 18 and one other, yet unidentified, ${ }^{\S}$ diastereoisomeric diol. While the presence of the 4'-O-acetate 18 could be simply explained by a lower base-promoted $O$-deacetylation rate with respect to the monosaccharide analogue, ${ }^{8 c}$ it is difficult to imagine the formation of the 3 '-O-acetate 19 directly from $\mathbf{1 8}$ through an acetyl shift taking place, after the reduction, from the axial $\mathrm{OH}-4$ ' group to the axial anti 3'-OH one. A better hypothesis as why $\mathbf{1 9}$ is formed would be an acyl shift on an enolic intermediate such as $\mathbf{2 8}$, where the 3'-OH group and the 4'-OAc one are co-planar (Scheme 3). The enolization of $\mathbf{1 7}$ could explain both the migration of the acetyl group and the loss of stereochemical purity either at C-4' and C-3', giving rise to the isolation in low amount also of a unidentified diastereoisomeric diol.

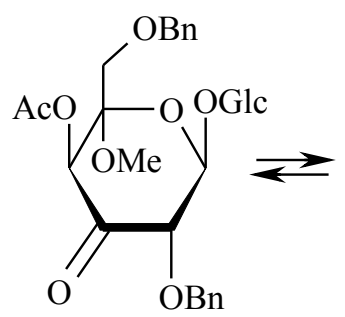

17

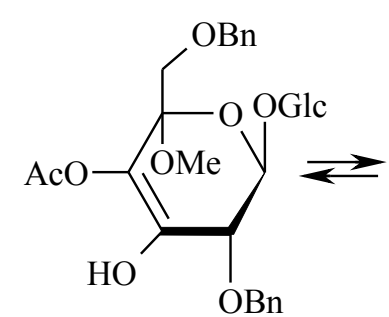

28

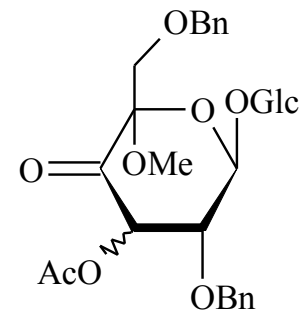

29

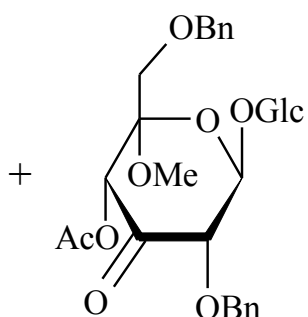

30

Scheme 3. Base-promoted isomerization of the uloside 17

The $O$-deacetylation of $20(\mathrm{MeONa}-\mathrm{MeOH})$ afforded quantitatively 21, raising its overall yield to an acceptable 65\%. Diol 21 was finally subjected to acid hydrolysis $\left(\mathrm{CF}_{3} \mathrm{COOH}-\mathrm{CH}_{3} \mathrm{CN}\right.$-water $)$ to give the previously reported 2,6-di-O-benzyl-L-lyxo-aldohexos-5-ulose (26). ${ }^{8 c}$

The problems encountered in the reduction of $\mathbf{1 7}$ could be avoided simplifying the chromatographic purifications, by changing the protection of the 4'-OH group from the acetate to a base-stable ethereal one. The direct monobenzylation of $\mathbf{8}$ was considered as the method of choice for the 4'regioselelective protection on the basis of the findings from Bernet and Vasella, ${ }^{14}$ which underlined, both in sugars and inositols, an enhanced acidity for axial hydroxy groups having a vicinal anti alkoxy group. The benzylation with $\mathrm{BnBr}$ ( 1 equiv) and $\mathrm{NaH}$ in $\mathrm{DMF}$ at $0^{\circ} \mathrm{C}$ pleasantly led to the 4'-O-monobenzylated derivative 22, isolated in a satisfactory $75 \%$ yield, after an easy chromatographic separation from the 3,4-di-O-benzyl derivative 23 (Scheme 2). No traces of the product of 3'-O-monobenzylation (14) were observed at any stage of the reaction. A specific role of

\footnotetext{
${ }^{\S}$ Unexpectedly, this second diastereoisomeric diol did not correspond to the L-arabino derivative 8. Owing to the difficulties to obtain a pure sample of this compound, present in the crude reaction mixture in low yield (about 13\%), we abandoned any effort to further elucidate its structure, a point that was out of the scope of the present work.
} 
the axial 5'-OMe in enhancing the acidity of 4'-OH is outlined by comparing the lower regioselectivity in the mono-benzylation of methyl 2,6-di-O-benzyl- $\beta$-D-galactopyranoside where 3$\mathrm{OH}$ and 4-OH alkylation products were obtained in a 1:2 ratio. ${ }^{15}$ The alcohol 22 was then submitted to an oxidation reaction with TPAP-NMO and the desired 3'-ulosyl derivative $\mathbf{2 4}$ was obtained in $76 \%$ yield. The reduction of $\mathbf{2 4}$ with $\mathrm{NaBH}_{4}$ in $\mathrm{MeOH}$ afforded 25 in a completely stereoselective way, owing to the negative 1,3-syn di-axial interaction between the 5'-OMe group and the hydride attacking from the $\alpha$ face. 2,4,6-Tri-O-benzyl-L-lyxo aldohexos-5-ulose 27 was obtained after removal of the acetal groups by acid hydrolysis $\left(\mathrm{CF}_{3} \mathrm{COOH}, \mathrm{CH}_{3} \mathrm{CN}\right.$-water) and its NMR data were identical to those of the sample previously reported, ${ }^{6 \mathrm{~b}}$ pointing to a complex tautomeric mixture, whose structure was indirectly confirmed by its transformation into the expected inosose. ${ }^{6 b}$

In conclusion, with this work the understanding of lactose potentiality as starting renewable material for the synthesis of fine chemicals has been increased preparing aldohexos-5-ulose derivatives of the D-xylo and L-lyxo series. The crucial role of the axial anomeric 5'-OMe group of the 1',5'-bis-glycosides has also been pinpointed in both the synthetic routes. In the first one, which leads to the $\mathrm{D}-x y$ lo derivative $\mathbf{1 5}$, it decreases the reactivity in the C-4' oxidation, and moreover turns completely the reactivity of the axial 4'-O-trifluoromethansulfonate from the substitution to the elimination, and, for steric reasons, inverts the outcome of the 4'-uloside reduction diastereoselection from an about complete galacto to a prevalent gluco. In the second synthetic pathway, leading to the L-lyxo hexos-5-ulose 27 , the presence of the axial C-5' methoxyl group allows the regioselective alkylation of 4'-OH group and the completely stereoselective reduction of the intermediate 3 '-uloside.

\section{Experimental}

\subsection{General methods}

General methods are those reported in Ref. 16. Compound $\mathbf{8}$ was prepared according to the described procedure. ${ }^{9}$

\section{2. (5R)-2,3,6-Tri- $O$-benzyl-5- $C$-methoxy- $\alpha$-L-arabino-hexopyranosyl-(1 $\rightarrow 4)-2,3: 5,6-d i-O$ - isopropylidene-aldehydo-D-glucose dimethyl acetal (9)}

A soln of $\mathbf{8}^{9}(3.94 \mathrm{~g}, 5.80 \mathrm{mmol})$ in toluene $(90 \mathrm{~mL})$ was treated with $\mathrm{Bu}_{2} \mathrm{SnO}(1.86 \mathrm{~g}, 7.44$ mmol), heated to reflux and subjected to azeotropical removal of water with a Dean-Stark apparatus. The reaction mixture was stirred at reflux $(12 \mathrm{~h})$ and then treated with $\mathrm{Bu}_{4} \mathrm{NBr}(944 \mathrm{mg}$, 
$2.90 \mathrm{mmol}), \mathrm{BnBr}(0.94 \mathrm{~mL}, 7.88 \mathrm{mmol})$ and further stirred until the starting material was disappeared (1.5 h, TLC, 7:3 hexane-EtOAc). The solvent was removed under diminished pressure and the residue $(9.02 \mathrm{~g}$ ) was subjected to flash chromatography (first hexane $400 \mathrm{~mL}$, then 7:3 hexane-EtOAc) to give $9(4.20 \mathrm{~g}, 94 \%$ yield $)$ as a colourless syrup; $[\alpha]_{\mathrm{D}}+4.0\left(c 1.2, \mathrm{CHCl}_{3}\right) ; R_{\mathrm{f}}$ 0.29 (7:3 hexane-EtOAc); ${ }^{1} \mathrm{H}$ NMR $\left(600 \mathrm{MHz}, \mathrm{CDCl}_{3}\right)$ : see Table 1 and $\delta$ 7.35-7.26 (m, 15H, Ar$\mathrm{H}), 4.84,4.68\left(\mathrm{AB}\right.$ system, $\left.2 \mathrm{H}, J_{\mathrm{A}, \mathrm{B}} 11.1 \mathrm{~Hz}, \mathrm{CH}_{2} \mathrm{Ph}\right), 4.72,4.47$ (AB system, 2H, $J_{\mathrm{A}, \mathrm{B}} 12.3 \mathrm{~Hz}$, $\mathrm{CH}_{2} \mathrm{Ph}$ ), 4.68 (s, 2H, $\left.\mathrm{CH}_{2} \mathrm{Ph}\right), 4.49$ (dd, $\left.1 \mathrm{H}, J_{1,2} 6.5 \mathrm{~Hz}, J_{2,3} 7.7 \mathrm{~Hz}, \mathrm{H}-2\right), 4.31$ (d, 1H, H-1), 4.26 (bq, 1H, H-5), 4.14 (dd, 1H, $\left.J_{5,6 \mathrm{~b}} 5.5 \mathrm{~Hz}, J_{6 \mathrm{a}, 6 \mathrm{~b}} 8.9 \mathrm{~Hz}, \mathrm{H}-6 \mathrm{~b}\right), 4.02$ (dd, 1H, $J_{3,4} 1.0 \mathrm{~Hz}, \mathrm{H}-3$ ), 3.88 (m, 1H, H-6a), 3.86 (dd, 1H, J4,5 5.8 Hz, H-4), 3.27, 3.26, 3.23 (3s, each 3H, $3 \times \mathrm{OMe}), 2.48(\mathrm{~d}, 1 \mathrm{H}$, $\left.J_{4^{\prime}, \mathrm{OH}} 1.9 \mathrm{~Hz}, \mathrm{OH}-4^{\prime}\right), 1.40,1.38,1.37,1.36\left(4 \mathrm{~s}\right.$, each $\left.3 \mathrm{H}, 2 \times \mathrm{CMe}_{2}\right) ;{ }^{13} \mathrm{C} \mathrm{NMR}\left(50 \mathrm{MHz}, \mathrm{CDCl}_{3}\right)$ : see Table 2 and $\delta$ 138.6, 138.0, 137.7 (3× Ar-C), 128.4-127.4 (Ar-CH), 109.9, $108.5\left(2 \times C \mathrm{Me}_{2}\right)$, 75.2, 73.5, $72.5\left(3 \times \mathrm{CH}_{2} \mathrm{Ph}\right)$, 55.7, $52.5(2 \times \mathrm{OMe}-1), 47.9\left(\mathrm{OMe}-5{ }^{\prime}\right), 27.3,26.9,26.5,25.3(2 \times$ $\mathrm{CMe}_{2}$ ). Anal. Calcd for $\mathrm{C}_{42} \mathrm{H}_{56} \mathrm{O}_{13}$ : C, 65.61; H, 7.34. Found: C, 65.70; H, 7.39.

3.3.

(5R)-2,3,6-Tri- $O$-benzyl-4- $O$-trifluomethansulfonyl-5- $C$-methoxy- $\alpha$-L-arabinohexopyranosyl-( $1 \rightarrow 4)-2,3: 5,6$-di-O-isopropylidene-aldehydo-D-glucose dimethyl acetal (10)

To a soln of $9(213 \mathrm{mg}, 0.277 \mathrm{mmol})$ in dry 1:1 $\mathrm{Py}-\mathrm{CH}_{2} \mathrm{Cl}_{2}(3 \mathrm{~mL})$ cooled to $-14{ }^{\circ} \mathrm{C}$ was added drop wise $\mathrm{Tf}_{2} \mathrm{O}(55 \mu \mathrm{L}, 0.333 \mathrm{mmol})$ dissolved in dry $\mathrm{CH}_{2} \mathrm{Cl}_{2}(10 \mathrm{~mL})$. The mixture was warmed to room temp and stirred until the starting material was disappeared (6 h, TLC, 6:4 hexane-EtOAc). 8 $\mathrm{mL}$ of satd aq $\mathrm{NaHCO}_{3}$ were added and the mixture partitioned between water and $\mathrm{CH}_{2} \mathrm{Cl}_{2}$. The aq phase was extracted with $\mathrm{CH}_{2} \mathrm{Cl}_{2}(3 \times 25 \mathrm{~mL})$, the organic extracts collected, dried $\left(\mathrm{MgSO}_{4}\right)$ and concentrated under diminished pressure. The residue $(264 \mathrm{mg})$ was subjected to flash chromatography $\left(3: 1\right.$ hexane-EtOAc) to give $\mathbf{1 0}(0.221 \mathrm{~g}, 88 \%$ yield $)$ as a colourless syrup; $[\alpha]_{\mathrm{D}}$ +15.7 ( c 1.2, $\left.\mathrm{CHCl}_{3}\right) ; R_{\mathrm{f}} 0.29$ (7:3 hexane-EtOAc); ${ }^{1} \mathrm{H}$ NMR $\left(250 \mathrm{MHz}, \mathrm{CD}_{3} \mathrm{CN}\right)$ : see Table 1 and $\delta$ 7.59-7.27 (m, 15H, Ar-H), 4.83, 4.59 (AB system, 2H, $\left.J_{\mathrm{A}, \mathrm{B}} 11.3 \mathrm{~Hz}, \mathrm{CH}_{2} \mathrm{Ph}\right), 4.79,4.67(\mathrm{AB}$ system, 2H, $J_{\mathrm{A}, \mathrm{B}} 11.4 \mathrm{~Hz}, \mathrm{CH}_{2} \mathrm{Ph}$ ), 4.63, 4.49 (AB system, 2H, $\left.J_{\mathrm{A}, \mathrm{B}} 11.5 \mathrm{~Hz}, \mathrm{CH}_{2} \mathrm{Ph}\right), 4.36(\mathrm{~m}, 2 \mathrm{H}$, H-1, H-2), 4.24 (bq, 1H, H-5), 4.08 (dd, 1H, J5,6b 5.7 Hz, J6a,6b 8.6 Hz, H-6b), 4.03 (m, 1H, J3,4 1.7 Hz, H-3), 3.88 (dd, 1H, $J_{4,5} 5.9$ Hz, H-4), 3.87 (dd, 1H, J5,6 5.4 Hz, H-6a), 3.32 (s, 6H, 2 x OMe-1), $3.22\left(\mathrm{~s}, 3 \mathrm{H}, \mathrm{OMe}-5\right.$ '), 1.36, 1.35, 1.33, $1.26\left(4 \mathrm{~s}\right.$, each $\left.3 \mathrm{H}, 2 \times \mathrm{CMe}_{2}\right) ;{ }^{13} \mathrm{C} \mathrm{NMR}(62.9 \mathrm{MHz}$, $\left.\mathrm{CD}_{3} \mathrm{CN}\right)$ : see Table 2 and $\delta$ 139.2, 138.6, $138.4(3 \times \mathrm{Ar}-\mathrm{C}), 129.3-128.5(\mathrm{Ar}-\mathrm{CH}), 110.3,109.2(2 \times$ $\left.C \mathrm{Me}_{2}\right), 100.3\left(\mathrm{C}-1^{\prime}\right), 75.9,73.8,73.7\left(3 \times \mathrm{CH}_{2} \mathrm{Ph}\right)$, 56.5, $53.6(2 \times \mathrm{OMe}-1), 49.3\left(\mathrm{OMe}-5^{\prime}\right), 27.4$, 26.9, 26.7, $25.3\left(2 \times \mathrm{CMe}_{2}\right)$. Anal. Calcd for $\mathrm{C}_{42} \mathrm{H}_{53} \mathrm{~F}_{3} \mathrm{O}_{14} \mathrm{~S}: \mathrm{C}, 57.92 ; \mathrm{H}, 6.13 ; \mathrm{F}, 6.54 ; \mathrm{S}, 3.68$. Found: C, 57.94; H, 6.14; F, 6.56; S, 3.69. 
A soln of $10(102 \mathrm{mg}, 0.113 \mathrm{mmol})$ in dry toluene $(5 \mathrm{~mL})$ was treated at room temp with $\mathrm{Bu}_{4} \mathrm{NNO}_{2}(147 \mathrm{mg}, 0.51 \mathrm{mmol})$ and warmed to reflux under stirring. After $8 \mathrm{~h}$ when the starting material was disappeared (TLC, 3:2 hexane-EtOAc) the mixture was cooled to room temp and concentrated under diminished pressure. The residue $(160 \mathrm{mg})$ was subjected to flash chromatography $\left(4: 1\right.$ hexane-EtOAc), to give $11\left(60 \mathrm{mg}, 70 \%\right.$ yield) as a colourless syrup; $[\alpha]_{\mathrm{D}}$ -24.0 (c 1.36, $\left.\mathrm{CHCl}_{3}\right) ; R_{\mathrm{f}} 0.29$ (7:3 hexane-EtOAc); ${ }^{1} \mathrm{H}$ NMR $\left(250 \mathrm{MHz}, \mathrm{CD}_{3} \mathrm{CN}\right)$ : see Table 1 and $\delta$ 7.43-7.25 (m, 15H, Ar-H), 4.90, 4.84 (AB system, 2H, $\left.J_{\mathrm{A}, \mathrm{B}} 11.9 \mathrm{~Hz}, \mathrm{CH}_{2} \mathrm{Ph}\right), 4.74$ (s, 2H, $\mathrm{CH}_{2} \mathrm{Ph}$ ), 4.55, 4.49 (AB system, 2H, $J_{\mathrm{A}, \mathrm{B}} 12.0 \mathrm{~Hz}, \mathrm{CH}_{2} \mathrm{Ph}$ ), 4.37 (d, 1H, $\left.J_{1,2} 5.5 \mathrm{~Hz}, \mathrm{H}-1\right), 4.34$ (dd, $1 \mathrm{H}, J_{2,3}$ $6.4 \mathrm{~Hz}, \mathrm{H}-2), 4.23$ (m, 1H, H-5), 4.12 (dd, 1H, $\left.J_{5,6 \mathrm{~b}} 1.3 \mathrm{~Hz}, J_{6 \mathrm{a}, 6 \mathrm{~b}} 8.5 \mathrm{~Hz}, \mathrm{H}-6 \mathrm{~b}\right), 4.06$ (dd,1H, $J_{3,4} 1.6$ Hz, H-3), 4.03 (dd, 1H, J5,6a 6.1 Hz, H-6a), 3.88 (dd, 1H, J4,5 5.3 Hz, H-4), 3.34, 3.30, 3.25 (3s, each $3 \mathrm{H}, 2 \times \mathrm{OMe}^{-1}$, OMe-5'), 1.33, 1.32, 1.30, $1.26\left(4 \mathrm{~s}\right.$, each $\left.3 \mathrm{H}, 2 \times \mathrm{CMe}_{2}\right) ;{ }^{13} \mathrm{C} \mathrm{NMR}(62.9 \mathrm{MHz}$, $\left.\mathrm{CD}_{3} \mathrm{CN}\right)$ : see Table 2 and $\delta$ 139.5, 139.4, 137.8 (3 × Ar-C), 129.4-128.6 (Ar-CH), 110.5, $109.1(2 \times$ $\left.C \mathrm{Me}_{2}\right)$, 74.8, 74.1, $73.0\left(3 \times \mathrm{CH}_{2} \mathrm{Ph}\right)$, 56.6, 53.5 (2 $\times$ OMe-1), 50.0 (OMe-5'), 27.5, 27.1, 26.8, 25.4 $\left(2 \times \mathrm{CMe}_{2}\right)$. Anal. Calcd for $\mathrm{C}_{41} \mathrm{H}_{52} \mathrm{O}_{11}: \mathrm{C}, 68.31 ; \mathrm{H}, 7.27$. Found: C, 68.35; H, 7.29.

\section{5. (5R)-2,3,6-Tri-O-benzyl-5- $C$-methoxy- $\alpha$-L-threo-hex-4-ulopyranosyl-(1 $\rightarrow 4)-2,3: 5,6$-di- $O$ - isopropylidene-aldehydo-D-glucose dimethyl acetal (12)}

A soln of 9 (493 mg, $0.641 \mathrm{mmol})$ in dry $\mathrm{CH}_{2} \mathrm{Cl}_{2}(12 \mathrm{~mL})$ and pre-dried 4-methylmorpholine- $N$ oxide (NMO) (123 mg, $1.05 \mathrm{mmol})$ containing $4 \AA ̊$ powdered molecular sieves (120 mg) was stirred under argon atmosphere for $30 \mathrm{~min}$ at room temp. Tetrapropylammonium perruthenate (TPAP) (90 $\mathrm{mg}, 40 \%$ ) was added and the resulting green mixture was stirred further $4 \mathrm{~h}$ at room temp. The reaction mixture was filtered through alternate paths of Celite and silica gel and extensively washed with $\mathrm{CH}_{2} \mathrm{Cl}_{2}$ and then EtOAc. The combined organic phases were concentrated under diminished pressure to give a syrup $(439 \mathrm{mg})$ constituted $\left({ }^{13} \mathrm{C} \mathrm{NMR}, \mathrm{CDCl}_{3}\right)$ by a mixture of 12 and 13 in a ratio of about 4:1 estimated on the basis of the relative 5'-OMe signal intensities. Flash chromatographic purification of the crude residue, eluting with 6:4 hexane-EtOAc, gave a 4:1 mixture of 12 and 13 (276 mg combined yield about 56\%) as a colourless syrup; $[\alpha]_{\mathrm{D}}+9.3(c 1.1$, $\left.\mathrm{CHCl}_{3}\right) ; R_{\mathrm{f}} 0.92\left(9: 1 \quad \mathrm{CH}_{2} \mathrm{Cl}_{2}-\mathrm{Me}_{2} \mathrm{CO}\right)$; selected ${ }^{13} \mathrm{C} \mathrm{NMR}\left(50 \mathrm{MHz}, \mathrm{CD}_{3} \mathrm{CN}\right)$ signals: major component 12: $\delta 198.3\left(\mathrm{C}^{4}{ }^{\prime}\right), 139.7,137.4,137.3(3 \times \mathrm{Ar}-\mathrm{C}), 110.4,109.2\left(2 \times \mathrm{CMe}_{2}\right), 106.6$ (C-1), 99.4 (C-5'), 99.1 (C-1'), 84.7, 82.3 (C-2', C-3'), 78.4, 77.9 (C-3, C-5), 76.7, 75.9 (C-4, C-2), 
75.7, 75.7, $74.1\left(3 \times \mathrm{CH}_{2} \mathrm{Ph}\right), 67.2,66.0(\mathrm{C}-6, \mathrm{C}-6$ ') $, 56.6,53.9(2 \times \mathrm{OMe}-1), 50.2(\mathrm{OMe}-5$ ') ; minor component 13: $\delta$ 139.8, 138.9, $138.2(3 \times \mathrm{Ar}-\mathrm{C}), 110.3,109.2\left(2 \times C \mathrm{Me}_{2}\right), 106.4(\mathrm{C}-1), 99.4\left(\mathrm{C}-5^{\prime}\right)$, 99.4 (C-1'), 97.1 (C-4'), 82.5, 81.5 (C-2', C-3'), 81.4, 78.4 (C-3, C-5), 77.6, 77.5 (C-4, C-2), 76.4, 75.7, $74.1\left(3 \times \mathrm{CH}_{2} \mathrm{Ph}\right), 70.3,66.0\left(\mathrm{C}-6, \mathrm{C}-6{ }^{\prime}\right), 56.4,53.6(2 \times \mathrm{OMe}-1), 48.8\left(\mathrm{OMe}-5^{\prime}\right)$. Cluster of signals for both components: $\delta$ 129.4-127.5 (Ar-CH), 27.8-25.4 $\left(\mathrm{CMe}_{2}\right)$.

\section{6. (5R)-2,3,6-Tri- $O$-benzyl-5- $C$-methoxy- $\beta$-D-xylo-hexopyranosyl-(1 $\rightarrow 4)-2,3: 5,6$-di- $O$ - isopropylidene-aldehydo-D-glucose dimethyl acetal (14)}

A soln of the crude 12 and 13 mixture $(912 \mathrm{mg})$ in dry $\mathrm{MeOH}(50 \mathrm{~mL})$ was cooled at $0{ }^{\circ} \mathrm{C}$ and treated with $\mathrm{NaBH}_{4}(180 \mathrm{mg}, 4.77 \mathrm{mmol})$. The reaction mixture was gently warmed to room temp and left under stirring until the TLC analysis (7:3 hexane-EtOAc) showed the complete disappearance of the starting material $(1.5 \mathrm{~h})$. Water $(15 \mathrm{~mL})$ was added, the soln stirred for $30 \mathrm{~min}$, concentrated under diminished pressure and the residue partitioned between water $(40 \mathrm{~mL})$ and $\mathrm{CH}_{2} \mathrm{Cl}_{2}(80 \mathrm{~mL})$. The aq phase was extracted with $\mathrm{CH}_{2} \mathrm{Cl}_{2}(3 \times 80 \mathrm{~mL})$, the organic extracts were collected, dried $\left(\mathrm{MgSO}_{4}\right)$, concentrated under diminished pressure and the residue (869 $\mathrm{mg}$ ) subjected to flash chromatography over silica gel (7:3 hexane-EtOAc) to give 14 (583 $\mathrm{mg}, 64 \%$ yield) and 9 (187 mg, 20\% yield).

Compound 14: colourless syrup; $[\alpha]_{\mathrm{D}}-15.9$ (c 1.0, $\left.\mathrm{CHCl}_{3}\right) ; R_{\mathrm{f}} 0.12$ (7:3 hexane-EtOAc); ${ }^{1} \mathrm{H}$ NMR (200 MHz, $\mathrm{CD}_{3} \mathrm{CN}$ ): see Table 1 and $\delta$ 7.39-7.26 (m, 15H, Ar-H), 4.84, 4.66 (AB system, 2H, $J_{\mathrm{A}, \mathrm{B}} 11.4 \mathrm{~Hz}, \mathrm{CH}_{2} \mathrm{Ph}$ ), 4.81, 4.75 (AB system, $2 \mathrm{H}, J_{\mathrm{A}, \mathrm{B}} 11.3 \mathrm{~Hz}, \mathrm{CH}_{2} \mathrm{Ph}$ ), 4.62, 4.48 (AB system, 2H, $\left.J_{\mathrm{A}, \mathrm{B}} 11.8 \mathrm{~Hz}, \mathrm{CH}_{2} \mathrm{Ph}\right), 4.48\left(\mathrm{dd}, 1 \mathrm{H}, J_{1,2} 6.3 \mathrm{~Hz}, J_{2,3} 7.4 \mathrm{~Hz}, \mathrm{H}-2\right), 4.33$ (d, 1H, H-1), 4.21 (m, 1H, H-5), 4.09 (dd, 1H, J5,6b 5.7 Hz, J6a,6b 8.5 Hz, H-6b), 4.08 (dd, 1H, J3,4 1.6 Hz, H-3), 3.87 (dd, 1H, $\left.J_{5,6 \mathrm{a}} 6.2 \mathrm{~Hz}, \mathrm{H}-6 \mathrm{a}\right), 3.85$ (bd, 1H, H-4), 3.36, 3.32, 3.30 (3s, each 3H, $2 \times$ OMe-1, OMe-5'), 1.36, $1.35,1.34,1.26\left(4 \mathrm{~s}\right.$, each $\left.3 \mathrm{H}, 2 \times \mathrm{CMe}_{2}\right) ;{ }^{13} \mathrm{C} \mathrm{NMR}\left(50 \mathrm{MHz}, \mathrm{CD}_{3} \mathrm{CN}\right)$ : see Table 2 and $\delta 140.2$, 139.7, $139.2(3 \times \mathrm{Ar}-\mathrm{C}), 129.3-128.2(\mathrm{Ar}-\mathrm{CH}), 110.4,109.2\left(2 \times \mathrm{CMe}_{2}\right), 75.7,75.5,74.3(3 \times$ $\left.\mathrm{CH}_{2} \mathrm{Ph}\right), 56.6,54.3(2 \times \mathrm{OMe}-1), 49.0\left(\mathrm{OMe}-5{ }^{\prime}\right), 27.5,27.1,27.0,25.5\left(2 \times \mathrm{CMe}_{2}\right)$. Anal. Calcd for $\mathrm{C}_{42} \mathrm{H}_{56} \mathrm{O}_{13}$ : C, 65.61; H, 7.34. Found: C, 65.73; H, 7.38.

Compound 9: colourless syrup; NMR parameters were identical to those of the sample prepared above.

\subsection{2,3,6-Tri-O-benzyl-D-xylo-hexos-5-ulose (15)}

A soln of $14(276 \mathrm{mg}, 0.359 \mathrm{mmol})$ in $4: 1(\mathrm{v} / \mathrm{v}) \mathrm{CH}_{3} \mathrm{CN}$-water $(7 \mathrm{~mL})$ was treated with $90 \%$ aq $\mathrm{CF}_{3} \mathrm{COOH}(1.4 \mathrm{~mL})$ warmed to $50{ }^{\circ} \mathrm{C}$ and stirred until the $\mathrm{TLC}$ analysis (EtOAc) showed the 
complete disappearance of the starting material $(12 \mathrm{~h})$. The mixture was concentrated under diminished pressure and repeatedly co-evaporated with toluene $(4 \times 20 \mathrm{~mL})$ under diminished pressure. The crude residue was partitioned between brine $(20 \mathrm{~mL})$ and EtOAc $(30 \mathrm{~mL})$ and the aq phase extracted with EtOAc $(3 \times 30 \mathrm{~mL})$. The organic phases were collected, dried $\left(\mathrm{MgSO}_{4}\right)$, concentrated under diminished pressure to give a residue $(125 \mathrm{mg})$, that was directly filtered on silica gel eluting with 3:7 hexane-EtOAc, to give pure 15 (122 mg, 72\% yield) as colourless syrup. NMR data were in full agreement with the reported ones. ${ }^{8 b}$

\section{8. (5R)-4- $O$-Acetyl-2,6-di- $O$-benzyl-5- $C$-methoxy- $\alpha$-L-arabino-hexopyranosyl-(1 $\rightarrow 4)-2,3: 5,6-$ di-O-isopropylidene-aldehydo-D-glucose dimethyl acetal (16)}

To a soln of $\mathbf{8}^{9}(341 \mathrm{mg}, 0.502 \mathrm{mmol})$ in dry toluene $(10 \mathrm{~mL})$ warmed to $45{ }^{\circ} \mathrm{C}, \mathrm{CH}_{3} \mathrm{C}(\mathrm{OEt})_{3}(1.1$ $\mathrm{mL}, 6.02 \mathrm{mmol})$ and TsOH $(9.5 \mathrm{mg}, 0.05 \mathrm{mmol})$ were added. The soln was stirred for $2 \mathrm{~h}$ at $45^{\circ} \mathrm{C}$ until the TLC analysis (1:1 hexane-EtOAc) showed the complete disappearance of the starting material $\left(R_{\mathrm{f}} 0.38\right)$ and the formation a faster moving product $\left(R_{\mathrm{f}} 0.60\right)$. The mixture was allowed to obtain room temp, treated with $\mathrm{Et}_{3} \mathrm{~N}(0.1 \mathrm{~mL})$ and further stirred for $10 \mathrm{~min}$. The soln was concentrated at diminished pressure and the residue $(228 \mathrm{mg})$ was treated with $80 \%$ aq AcOH $(3.0$ $\mathrm{mL}$ ) and stirred at room temp until the product at $R_{\mathrm{f}} 0.60$ was completely reacted (TLC, 1:1 hexaneEtOAc, $15 \mathrm{~min})$. The mixture was diluted with $\mathrm{CH}_{2} \mathrm{Cl}_{2}(20 \mathrm{~mL})$ and carefully neutralized with $40 \%$ aq $\mathrm{NaOH}(4 \mathrm{~mL})$. The reaction mixture was diluted with water $(7 \mathrm{~mL})$ and the aq phase was extracted with $\mathrm{CH}_{2} \mathrm{Cl}_{2}(3 \times 20 \mathrm{~mL})$. The combined organic layers were dried $\left(\mathrm{MgSO}_{4}\right)$, filtered, and concentrated under diminished pressure. The residue (356 mg) was constituted exclusively (NMR) of 16 (quantitative yield). An analytical sample of $\mathbf{1 6}$ was obtained through flash chromatography eluting with 3:2 hexane-EtOAc. Pure 16 (308 mg, 85\% yield) was a white foam; $[\alpha]_{\mathrm{D}}-24.2$ (c 0.95, $\left.\mathrm{CHCl}_{3}\right) ; R_{\mathrm{f}} 0.51$ (1:1 hexane-EtOAc); ${ }^{1} \mathrm{H}$ NMR (200 MHz, $\left.\mathrm{CDCl}_{3}\right)$ : see Table 1 and $\delta$ 7.35-7.26 (m, 10H, Ar-H), 4.92, 4.59 (AB system, 2H, $J_{\mathrm{A}, \mathrm{B}} 11.3 \mathrm{~Hz}, \mathrm{CH}_{2} \mathrm{Ph}$ ), 4.49 (dd, $1 \mathrm{H}, J_{1,2} 6.7 \mathrm{~Hz}, J_{2,3} 7.0 \mathrm{~Hz}$, H-2), 4.46 (s, 2H, $\mathrm{CH}_{2} \mathrm{Ph}$ ), 4.32 (d, 1H, H-1), 4.30-3.95 (m, 5H, H-3, H-4, H-5, H-6a, H-6b), 3.34, 3.33 (2s, each 3H, $\left.2 \times \mathrm{OMe}^{-1}\right), 3.27$ (s, 3H, OMe-5'), 2.22 (bs, 1H, OH-3'), 1.96 (s, 3H, MeCO), 1.45, $1.32\left(2 \mathrm{~s}\right.$, each $\left.3 \mathrm{H}, \mathrm{CMe} e_{2}\right), 1.41\left(\mathrm{~s}, 6 \mathrm{H}, \mathrm{CMe} e_{2}\right) ;{ }^{13} \mathrm{C} \mathrm{NMR}\left(50 \mathrm{MHz}, \mathrm{CDCl}_{3}\right): \delta$ see Table 2 and 169.5 (MeCO), 137.8, 136.9 (2 × Ar-C), 129.4-127.4 (Ar-CH), 109.6, $108.1\left(2 \times C \mathrm{Me}_{2}\right), 74.3,73.1$

$\left(2 \times \mathrm{CH}_{2} \mathrm{Ph}\right), 55.6,52.9\left(2 \times \mathrm{OMe}^{-1}\right), 47.8\left(\mathrm{OMe}^{\prime}\right), 26.8,26.1,26.0,24.7\left(2 \times \mathrm{CMe}_{2}\right), 20.4$ (MeCO). Anal. Calcd for $\mathrm{C}_{37} \mathrm{H}_{52} \mathrm{O}_{14}: \mathrm{C}, 61.65 ; \mathrm{H}, 7.27$. Found: C, 61.59; H, 7.23.

3.9. Oxidation-reduction of (5R)-4-O-Acetyl-2,6-di-O-benzyl-5- $C$-methoxy- $\alpha$-L-arabinohexopyranosyl-( $1 \rightarrow 4)-2,3: 5,6$-di-O-isopropylidene-aldehydo-D-glucose dimethyl acetal (16) 
3.9.1. Oxidation of 16. - A suspension of $\mathbf{1 6}(356 \mathrm{mg}, 0.494 \mathrm{mmol})$ in dry $\mathrm{CH}_{2} \mathrm{Cl}_{2}(6 \mathrm{~mL})$ and predried 4-methylmorpholine- $N$-oxide (NMO) (98 mg, $0.841 \mathrm{mmol}$ ) containing $4 \AA$ powdered molecular sieves $(250 \mathrm{mg})$ was stirred under argon atmosphere for $30 \mathrm{~min}$ at room temp. Tetrapropylammonium perruthenate (TPAP) (35 mg, 20\%) was added and the resulting green mixture was stirred until the TLC analysis (13:7 hexane-EtOAc) revealed the disappearance of the starting material (45 $\mathrm{min}, R_{\mathrm{f}}$ 0.25). The reaction mixture was filtered through alternate paths of Celite and silica gel and extensively washed first with $\mathrm{CH}_{2} \mathrm{Cl}_{2}$ and then with EtOAc. The combined organic phases were concentrated under diminished pressure to give a syrup (352 $\mathrm{mg}$ ) constituted exclusively (NMR) by the uloside 17; $R_{\mathrm{f}} 0.17$ (13:7 hexane-EtOAc); ${ }^{1} \mathrm{H}$ NMR $\left(200 \mathrm{MHz}, \mathrm{CDCl}_{3}\right)$ : see Table 1 and $\delta$ 7.30-7.22 (m, 10H, Ar-H), 4.80, 4.65 (AB system, 2H, $J_{\mathrm{A}, \mathrm{B}} 11.9 \mathrm{~Hz}, \mathrm{CH}_{2} \mathrm{Ph}$ ), 4.52, 4.43 (AB system, 2H, $J_{\mathrm{A}, \mathrm{B}} 12.4 \mathrm{~Hz}, \mathrm{CH}_{2} \mathrm{Ph}$ ), 4.46 (dd, $\left.1 \mathrm{H}, J_{1,2} 6.6 \mathrm{~Hz}, J_{2,3} 7.1 \mathrm{~Hz}, \mathrm{H}-2\right), 4.32$ (d, 1H, H-1), 4.25 (m, 1H, H-5), 4.17-3.85 (m, 4H, H-3, H-4, H-6a, H-6b), 3.36 (s, 6H, $2 \times$ OMe-1), 3.29 (s, 3H, OMe-5'), 1.86 (s, 3H, MeCO), 1.41, 1.38, 1.35, 1.31 (4s, each 3H, 2 x CMe $)$; ${ }^{13} \mathrm{C}$ NMR $\left(50 \mathrm{MHz}, \mathrm{CDCl}_{3}\right)$ : see Table 2 and $\delta 168.5(\mathrm{MeCO}), 137.1,136.8(2 \times \mathrm{Ar}-\mathrm{C}), 129.7-127.8(\mathrm{Ar}-\mathrm{CH})$, 109.9, $108.6\left(2 \times \mathrm{CMe}_{2}\right), 73.2,72.9\left(2 \times \mathrm{CH}_{2} \mathrm{Ph}\right), 56.2,53.6(2 \times \mathrm{OMe}-1), 48.7(\mathrm{OMe}-5 '), 27.2,26.5$, 26.3, $25.3\left(2 \times \mathrm{CMe}_{2}\right), 20.3(\mathrm{MeCO})$.

3.9.2. Reduction of 17. - A soln of crude 17 (352 mg, $0.489 \mathrm{mmol})$ in dry $\mathrm{MeOH}(10 \mathrm{~mL})$ was cooled to $0{ }^{\circ} \mathrm{C}$ and treated, under argon atmosphere, with $\mathrm{NaBH}_{4}(138 \mathrm{mg}, 3.65 \mathrm{mmol})$. The reaction mixture was gently warmed to room temp and left under stirring until the TLC analysis (1:1 hexane-EtOAc) showed the complete disappearance of the starting material (30 min). Water $(15 \mathrm{~mL})$ was added, the soln was stirred for $4 \mathrm{~h}$, concentrated under diminished pressure and the residue partitioned between water $(20 \mathrm{~mL})$ and $\mathrm{CH}_{2} \mathrm{Cl}_{2}(40 \mathrm{~mL})$. The aq phase was extracted with $\mathrm{CH}_{2} \mathrm{Cl}_{2}(5 \times 25 \mathrm{~mL})$ and the organic extracts were collected, dried $\left(\mathrm{MgSO}_{4}\right)$ and concentrated under diminished pressure. The residue $(307 \mathrm{mg}$ ) was subjected to flash chromatography (first 11:9 hexane-EtOAc, then 2:3 hexane-EtOAc) collecting four main fractions. The first two fractions were constituted by the monoacetates $18(65 \mathrm{mg})$ and $19(120 \mathrm{mg})$, each in mixture with about $10 \%$ of the other, accounting for an overall 52\% yield, the third fraction contained pure diol 21 (43 mg, $13 \%$ yield), and the fourth one an about 1:1 mixture of 21 and another yet unidentified diastereoisomeric diol (86 mg, each about 13\% yield).

(5R)-4-O-Acetyl-2,6-di-O-benzyl-5-C-methoxy- $\alpha$-L-xylo-hexopyranosyl-(1 $\rightarrow 4)-2,3: 5,6$-di-Oisopro-pylidene-aldehydo-D-glucose dimethyl acetal (18): $R_{\mathrm{f}} 0.39$ (1:1 hexane-EtOAc); ${ }^{1} \mathrm{H}$ NMR $\left(200 \mathrm{MHz}, \mathrm{CDCl}_{3}\right)$ : see Table 1 and $\delta$ 7.34-7.18 (m, 10H, Ar-H), 4.71, $4.59\left(\mathrm{AB}\right.$ system, 2H, $J_{\mathrm{A}, \mathrm{B}}$ $12.0 \mathrm{~Hz}, \mathrm{CH}_{2} \mathrm{Ph}$ ), 4.56, 4.49 (AB system, $2 \mathrm{H}, J_{\mathrm{A}, \mathrm{B}} 12.0 \mathrm{~Hz}, \mathrm{CH}_{2} \mathrm{Ph}$ ), 4.42 (dd, $1 \mathrm{H}, J_{1,2} 6.4 \mathrm{~Hz}, J_{2,3}$ 7.0 Hz, H-2), 4.32 (d, 1H, H-1), 4.25 (m, 2H, H-5, H-6a), 4.05-3.90 (m, 3H, H-3, H-4, H-6b), 3.32, 
3.30. $3.29\left(3 \mathrm{~s}\right.$, each 3H, $\left.2 \times \mathrm{OMe}^{-1}, \mathrm{OMe}-5^{\prime}\right), 2.69\left(\mathrm{~d}, 1 \mathrm{H}, J_{4^{\prime}, \mathrm{OH}} 5.3 \mathrm{~Hz}, \mathrm{OH}-4^{\prime}\right), 2.02$ (s, 3H, $\mathrm{MeCO}), 1.41,1.32(2 \mathrm{~s}$, each $3 \mathrm{H}, \mathrm{CMe}$ ); 1.40 (s, 6H, CMe $)$; ${ }^{13} \mathrm{C} \mathrm{NMR}\left(50 \mathrm{MHz}, \mathrm{CDCl}_{3}\right)$ : see Table 2 and $\delta 170.5(\mathrm{MeCO}), 138.2,137.4(2 \times \mathrm{Ar}-\mathrm{C}), 128.5-126.9(\mathrm{Ar}-\mathrm{CH}), 110.0,108.4\left(2 \times C \mathrm{Me}_{2}\right)$, 73.4, $72.6\left(2 \times \mathrm{CH}_{2} \mathrm{Ph}\right), 55.8,52.8(2 \times \mathrm{OMe}-1), 48.1\left(\mathrm{OMe}-5\right.$ ') , 27.3, 26.6, 26.3, $25.4\left(2 \times \mathrm{CMe}_{2}\right)$, 20.9 (MeCO). Anal. Calcd for $\mathrm{C}_{37} \mathrm{H}_{52} \mathrm{O}_{14}$ : C, 61.65; H, 7.27. Found: C, 61.58; H, 7.25.

(5R)-3-O-Acetyl-2,6-di-O-benzyl-5-C-methoxy- $\alpha$-L-xylo-hexopyranosyl-(1 $\rightarrow 4)-2,3: 5,6$-di-Oisopro-pylidene-aldehydo-D-glucose dimethyl acetal (19): $R_{\mathrm{f}} 0.34$ (1:1 hexane-EtOAc); ${ }^{1} \mathrm{H}$ NMR $\left(200 \mathrm{MHz}, \mathrm{CDCl}_{3}\right)$ : see Table 1 and $\delta$ 7.33-7.26 (m, 10H, Ar-H), 4.81, 4.63 (AB system, 2H, $J_{\mathrm{A}, \mathrm{B}}$ $12.1 \mathrm{~Hz}, \mathrm{CH}_{2} \mathrm{Ph}$ ), 4.47, 4.40 (AB system, $2 \mathrm{H}, J_{\mathrm{A}, \mathrm{B}} 11.7 \mathrm{~Hz}, \mathrm{CH}_{2} \mathrm{Ph}$ ), 4.47 (dd, $1 \mathrm{H}, J_{1,2} 6.4 \mathrm{~Hz}, J_{2,3}$ 7.6 Hz, H-2), 4.28-3.94 (m, 3H, H-5, H-6a, H-6b), 4.32 (d, 1H, H-1), 4.06 (dd, 1H, J3,4 1.2 Hz, H-3), $3.92\left(\mathrm{dd}, 1 \mathrm{H}, J_{4,5} 5.0 \mathrm{~Hz}, \mathrm{H}-4\right), 3.37,3.36,3.35$ (3s, each 3H, $2 \times$ OMe-1, OMe-5'), 3.14 (d, 1H, $\left.J_{3^{\prime}, \mathrm{OH}} 8.0 \mathrm{~Hz}, \mathrm{OH}-3^{\prime}\right), 1.78$ (s, 3H, MeCO), 1.43 (s, 6H, CMe $) ; 1.42,1.32\left(2 \mathrm{~s}\right.$, each $\left.3 \mathrm{H}, \mathrm{CMe}_{2}\right) ;{ }^{13} \mathrm{C}$ NMR (50 MHz, $\left.\mathrm{CDCl}_{3}\right)$ : see Table 2 and $\delta 168.5(\mathrm{MeCO}), 137.9,137.3(2 \times \mathrm{Ar}-\mathrm{C}), 128.3-127.6$ (Ar-CH), 109.9, $108.5\left(2 \times \mathrm{CMe}_{2}\right), 73.3,72.5\left(2 \times \mathrm{CH}_{2} \mathrm{Ph}\right)$, 56.1, 53.7 (2× OMe-1), $48.4\left(\mathrm{OMe}-5{ }^{\prime}\right)$, 27.2, 26.5, 26.4, $25.3\left(2 \times \mathrm{CMe}_{2}\right), 20.5$ (MeCO). Anal. Calcd for $\mathrm{C}_{37} \mathrm{H}_{52} \mathrm{O}_{14}: \mathrm{C}, 61.65 ; \mathrm{H}, 7.27$. Found: C, 61.60; H, 7.22.

(5R)-2,6-di-O-benzyl-5-C-methoxy- $\alpha$-L-xylo-hexopyranosyl-(1 $\rightarrow 4)$-2,3:5,6-di-O-isopropylidenealdehydo-D-glucose dimethyl acetal (21): white foam; $[\alpha]_{\mathrm{D}}-27.2$ (c $\left.0.99, \mathrm{CHCl}_{3}\right) ; R_{\mathrm{f}} 0.32(2: 3$ hexane-EtOAc); ${ }^{1} \mathrm{H}$ NMR (250 MHz, $\left.\mathrm{CDCl}_{3}\right): \delta$ 7.31-7.22 (m, 10H, Ar-H), $5.18\left(\mathrm{~d}, 1 \mathrm{H}, J_{1^{\prime}, 2^{\prime}} 7.8 \mathrm{~Hz}\right.$, H-1'), 4.81, 4.65 (AB system, 2H, $J_{\mathrm{A}, \mathrm{B}} 12.2 \mathrm{~Hz}, \mathrm{CH}_{2} \mathrm{Ph}$ ), 4.57, 4.50 (AB system, 2H, $J_{\mathrm{A}, \mathrm{B}} 12.3 \mathrm{~Hz}$, $\mathrm{CH}_{2} \mathrm{Ph}$ ), 4.47 (dd, 1H, $\left.J_{1,2} 6.7 \mathrm{~Hz}, J_{2,3} 7.1 \mathrm{~Hz}, \mathrm{H}-2\right), 4.31$ (d, 1H, H-1), 4.30-4.17 (m, 2H, H-5, H-6b), 4.05-3.98 (m, 5H, H-3', H-4', H-3, H-4, H-6a), 3.60-3.50 (m, 3H, H-2', H-6'a, H-6'b), 3.31 (s, 9H, $2 \times$ OMe-1, OMe-5'), 3.13 (d, 1H, $J_{3}^{\prime}$, OH 7.5 Hz, OH-3'), 2.60 (d, 1H, $J_{4}^{\prime}$, OH 5.2 Hz, OH-4'), 1.41 (s, 9H, $\left.\mathrm{CMe}_{2}\right) ; 1.32$ (s, 3H, $\left.\mathrm{CMe}_{2}\right) ;{ }^{13} \mathrm{C} \mathrm{NMR}\left(62.9 \mathrm{MHz}, \mathrm{CDCl}_{3}\right)$ : see Table 2 and $\delta 138.1,137.2(2$ $\times \mathrm{Ar}-\mathrm{C}), 128.5-127.5(\mathrm{Ar}-\mathrm{CH}), 109.9,108.5\left(2 \times \mathrm{CMe}_{2}\right), 73.3,72.6\left(2 \times \mathrm{CH}_{2} \mathrm{Ph}\right)$, 56.0, $53.1(2 \times$ OMe-1), 48.4 (OMe-5'), 27.2, 26.6, 26.5, 25.3 (2× CMe $)$. Anal. Calcd for $\mathrm{C}_{35} \mathrm{H}_{50} \mathrm{O}_{13}$ : C, 61.93; H, 7.42. Found: C, 61.90; H, 7.39.

Selected ${ }^{13} \mathrm{C}$ NMR $\left(50 \mathrm{MHz}, \mathrm{CDCl}_{3}\right.$ ) data for the unidentified diastereoisomeric diol isolated in mixture with 21: $\delta 106.0$ (C-1), 98.6 (C-5'), 98.2 (C-1'), 81.2 (C-2'), 77.8, 77.6, 77.3 (C-3, C-4, C-5), 75.5, 74.8, 71.6 (C-2, C-3', C-4'), 73.7, 73.74 (2 $\left.\times \mathrm{CH}_{2} \mathrm{Ph}\right), 69.9$ (C-6'), 65.2 (C-6), 56.0, 53.6 $(2 \times \mathrm{OMe}-1), 48.5\left(\mathrm{OMe}-5^{\prime}\right)$.

3.10. 
Compound 21 (40 mg, $0.059 \mathrm{mmol}$ ) was acetylated with a 1:2 mixture of $\mathrm{Ac}_{2} \mathrm{O}$ and pyridine (3 $\mathrm{mL}$ ) and stirred at room temp. After $20 \mathrm{~h}$ the reaction mixture was repeatedly co-evaporated with toluene $(4 \times 10 \mathrm{~mL})$ at diminished pressure. Flash chromatographic purification (13:7 hexaneEtOAc) of the residue (52 mg) gave 20 (44 mg, 97\% yield) as a syrup; $[\alpha]_{\mathrm{D}}-46.9\left(c 0.9, \mathrm{CHCl}_{3}\right) ; R_{\mathrm{f}}$ 0.38 (3:2 hexane-EtOAc); ${ }^{1} \mathrm{H}$ NMR (200 MHz, $\mathrm{CDCl}_{3}$ ): see Table 1 and $\delta$ 7.35-7.23 (m, 10H, Ar$\mathrm{H}), 4.68,4.58$ (AB system, 2H, $\left.J_{\mathrm{A}, \mathrm{B}} 11.9 \mathrm{~Hz}, \mathrm{CH}_{2} \mathrm{Ph}\right), 4.43,4.40$ (s, 2H, $\left.\mathrm{CH}_{2} \mathrm{Ph}\right), 4.46$ (dd, $1 \mathrm{H}, J_{1,2}$ $\left.6.5 \mathrm{~Hz}, J_{2,3} 7.3 \mathrm{~Hz}, \mathrm{H}-2\right), 4.33$ (d, 1H, H-1), 4.26 (m, 1H, H-5), 4.03 (dd, 1H, J3,4 1.3 Hz, H-3), 4.16 (dd, 1H, $\left.J_{5,6 \mathrm{~b}} 6.2 \mathrm{~Hz}, J_{6 \mathrm{a}, 6 \mathrm{~b}} 8.5 \mathrm{~Hz}, \mathrm{H}-6 \mathrm{~b}\right), 3.98$ (m, 2H, H-4, H-6a), 3.34, 3.33, 3.32 (3s, each 3H, $2 \times$ OMe-1, OMe-5'), 2.00, 1.85 (2s, each 3H, 2 x MeCO), 1.41 (s, 6H, CMe $)$; 1.40, 1.32 (2s, each 3H, $\left.\mathrm{CMe}_{2}\right) ;{ }^{13} \mathrm{C} \mathrm{NMR}\left(50 \mathrm{MHz}, \mathrm{CDCl}_{3}\right)$ : see Table 2 and $\delta$ 169.5, $168.1(2 \times \mathrm{MeCO}), 137.8,137.3(2 \times$ Ar-C), 128.4-127.5 (Ar-CH), 110.1, $108.4\left(2 \times \mathrm{CMe}_{2}\right), 73.4,72.6\left(2 \times \mathrm{CH}_{2} \mathrm{Ph}\right), 55.8,53.4(2 \times$ OMe-1), 48.1 (OMe-5'), 27.2, 26.6, 26.2, 25.4 (2× $\left.\mathrm{CMe}_{2}\right), 20.8,20.6$ (2 x MeCO). Anal. Calcd for $\mathrm{C}_{39} \mathrm{H}_{54} \mathrm{O}_{15}$ : C, 61.41; H, 7.14. Found: C, 61.38; H, 7.12.

The acetylation of either the fractions containing $19(115 \mathrm{mg}, 0.160 \mathrm{mmol})$ or $18(65 \mathrm{mg}, 0.090$ mmol) as reported above gave, after chromatographic purification (13:7 hexane-EtOAc), 21 (183 mg, 96\% yield) having NMR parameters identical to those of the sample prepared above.

3.11.

(5R)-2,6-di- $O$-benzyl-5- $C$-methoxy- $\alpha$-L-lyxo-hexopyranosyl-(1 $\rightarrow 4)-2,3: 5,6-d i-O$ isopropylidene-aldehydo-D-glucose dimethyl acetal (21)

To a soln of $20(183 \mathrm{mg}, 0.240 \mathrm{mmol})$ in dry $\mathrm{MeOH}(5 \mathrm{~mL})$ was added at room temp a $0.1 \mathrm{M}$ methanolic soln of $\mathrm{MeONa}(0.2 \mathrm{~mL})$. The reaction mixture was stirred until TLC analysis $(3: 2$ hexane-EtOAc) showed the complete disappearance of the starting material $(2 \mathrm{~h})$ and the formation of a lower moving product. The solution was neutralized with resin acid (Amberlyst 15) and the suspension was filtered and concentrated to give a foam residue constituted by pure (NMR) 21 (162.5 mg, quantitative yield), identical to the sample obtained above. The combined overall yield of 21, obtained by adding the sample directly isolated in the oxidation-reduction of 16 , was $65 \%$.

\subsection{2,6-Di-O-benzyl-L-lyxo-hexos-5-ulose (26)}

A soln of $21(185 \mathrm{mg}, 0.272 \mathrm{mmol})$ in $4: 1(\mathrm{v} / \mathrm{v}) \mathrm{CH}_{3} \mathrm{CN}$-water $(6 \mathrm{~mL})$ was treated with $90 \%$ aq $\mathrm{CF}_{3} \mathrm{COOH}\left(1.2 \mathrm{~mL}\right.$ ) warmed to $50{ }^{\circ} \mathrm{C}$ and stirred until TLC analysis (EtOAc) showed the complete disappearance of the starting material $(5 \mathrm{~h})$. The mixture was concentrated under diminished pressure and repeatedly co-evaporated with toluene $(5 \times 20 \mathrm{~mL})$. The residue was partitioned 
between brine $(20 \mathrm{~mL})$ and EtOAc $(40 \mathrm{~mL})$ and the aq phase extracted with EtOAc $(3 \times 40 \mathrm{~mL})$. The organic phases were collected, dried $\left(\mathrm{MgSO}_{4}\right)$, concentrated under diminished pressure to give a residue $(96 \mathrm{mg})$, that was directly subjected to a flash chromatographic purification, eluting with 1:3 hexane-EtOAc, to give pure 26 (75 mg, 78\% yield) as colourless syrup. NMR data were in agreement with the reported ones. ${ }^{8 b}$

\subsection{3. (5R)-2,4,6-Tri- $O$-benzyl-5- $C$-methoxy- $\alpha$-L-arabino-hexopyranosyl-( $1 \rightarrow 4)-2,3: 5,6$-di- $O$ - isopropylidene-aldehydo-D-glucose dimethyl acetal (22) and (5R)-2,3,4,6-tetra- $O$-benzyl-5-C- methoxy- $\alpha$-L-arabino-hexopyranosyl-(1 $\rightarrow$ 4)-2,3:5,6-di- $O$-isopropylidene-aldehydo-D-glucose dimethyl acetal (23)}

A suspension of pre-washed (hexane) $60 \% \mathrm{NaH}$ in mineral oil (1.29 g, $53.7 \mathrm{mmol})$ in dry DMF $(25.0 \mathrm{~mL})$ was cooled to $0{ }^{\circ} \mathrm{C}$ and treated, under argon atmosphere, with a soln of $8(3.62 \mathrm{~g}, 5.34$ $\mathrm{mmol})$ in dry DMF $(100 \mathrm{~mL})$. The mixture was warmed to room temp and stirred for $30 \mathrm{~min}$, cooled again to $0{ }^{\circ} \mathrm{C}$ and treated with $\mathrm{BnBr}(0.63 \mathrm{~mL}, 5.34 \mathrm{mmol})$ and further stirred until the starting material was consumed (25 min, TLC, 7:3 hexane-EtOAc). MeOH (12 mL) and water (100 $\mathrm{mL})$ were slowly added and the reaction mixture was extracted with $\mathrm{Et}_{2} \mathrm{O}(4 \times 50 \mathrm{~mL})$. The combined extracts were collected, dried $\left(\mathrm{MgSO}_{4}\right)$, concentrated under diminished pressure and the residue (4.68 g) subjected to flash chromatography (first hexane $600 \mathrm{~mL}$, then 4:1 hexane-EtOAc) to give 22 (3.09 g, 75\% yield) and 23 (684 mg, 15\% yield).

Compound 22 was a colourless syrup; $[\alpha]_{\mathrm{D}}+16.8\left(c 1.07, \mathrm{CHCl}_{3}\right) ; R_{\mathrm{f}} 0.24$ (7:3 hexane-EtOAc); ${ }^{1} \mathrm{H}$ NMR (600 MHz, $\mathrm{CDCl}_{3}$ ): see Table 1 and $\delta$ 7.36-7.22 (m, 15H, Ar-H), 4.76, 4.60 (AB system, $2 \mathrm{H}, J_{\mathrm{A}, \mathrm{B}} 11.6 \mathrm{~Hz}, \mathrm{CH}_{2} \mathrm{Ph}$ ), 4.62, 4.58 (AB system, $2 \mathrm{H}, J_{\mathrm{A}, \mathrm{B}} 11.3 \mathrm{~Hz}, \mathrm{CH}_{2} \mathrm{Ph}$ ), 4.58, 4.34 (AB system, 2H, $\left.J_{\mathrm{A}, \mathrm{B}} 12.1 \mathrm{~Hz}, \mathrm{CH}_{2} \mathrm{Ph}\right), 4.49$ (dd, $\left.1 \mathrm{H}, J_{1,2} 6.5 \mathrm{~Hz}, J_{2,3} 7.6 \mathrm{~Hz}, \mathrm{H}-2\right), 4.31$ (d, 1H, H-1), 4.27 (bq, 1H, H-5), 4.16 (dd, 1H, $\left.J_{5,6 \mathrm{~b}} 5.6 \mathrm{~Hz}, J_{6 \mathrm{a}, 6 \mathrm{~b}} 8.7 \mathrm{~Hz}, \mathrm{H}-6 \mathrm{~b}\right), 4.00$ (m, 1H, H-4), 3.95 (dd, 1H, J5,6a 6.2 Hz, H-6a), 3.92 (dd, 1H, J3,4 0.8 Hz, H-3), 3.27, 3.25, 3.22 (3s, each 3H, $2 \times$ OMe-1, OMe-5'), 1.43, 1.41, 1.38, $1.31\left(4 \mathrm{~s}\right.$, each 3H, $\left.2 \times \mathrm{CMe}_{2}\right) ;{ }^{13} \mathrm{C} \mathrm{NMR}\left(50 \mathrm{MHz}, \mathrm{CDCl}_{3}\right)$ : see Table 2 and $\delta 138.6$, 138.3, $137.2\left(3 \times\right.$ Ar-C), 128.3-127.2 (Ar-CH), 109.8, $108.4\left(2 \times \mathrm{CMe}_{2}\right), 74.9,74.5,73.2(3 \times$ $\left.\mathrm{CH}_{2} \mathrm{Ph}\right)$, 55.6, $52.3(2 \times \mathrm{OMe}-1), 47.9(\mathrm{OMe}-5 '), 27.2,26.5,26.4,25.0\left(2 \times \mathrm{CMe}_{2}\right)$. Anal. Calcd for $\mathrm{C}_{42} \mathrm{H}_{56} \mathrm{O}_{13}: \mathrm{C}, 65.61 ; \mathrm{H}, 7.34$. Found: C, 65.73; H, 7.44.

Compound 23 was a colourless syrup; $[\alpha]_{\mathrm{D}}+17.6\left(c\right.$ 1.2, $\left.\mathrm{CHCl}_{3}\right) ; R_{\mathrm{f}} 0.38$ (7:3 hexane-EtOAc); ${ }^{1} \mathrm{H}$ NMR (200 MHz, $\mathrm{CDCl}_{3}$ ): see Table 1 and $\delta$ 7.33-7.23 (m, 20H, Ar-H), 4.95, 4.57 (AB system, 2H, $\left.J_{\mathrm{A}, \mathrm{B}} 11.5 \mathrm{~Hz}, \mathrm{CH}_{2} \mathrm{Ph}\right), 4.83,4.73$ (AB system, 2H, $\left.J_{\mathrm{A}, \mathrm{B}} 10.7 \mathrm{~Hz}, \mathrm{CH}_{2} \mathrm{Ph}\right), 4.70$ (s, 2H, $\mathrm{CH}_{2} \mathrm{Ph}$ ), 4.56, 4.28 (AB system, 2H, $J_{\mathrm{A}, \mathrm{B}} 12.1 \mathrm{~Hz}, \mathrm{CH}_{2} \mathrm{Ph}$ ), 4.54 (dd, $\left.1 \mathrm{H}, J_{1,2} 6.7 \mathrm{~Hz}, J_{2,3} 9.7 \mathrm{~Hz}, \mathrm{H}-2\right), 4.31$ (d, 1H, H-1), 4.18 (m, 1H, H-5), 4.05 (m, 2H, H-4, H-6b), 3.98 (dd, 1H, J3,4 2.9 Hz, H-3), 3.87 (dd, 
$\left.1 \mathrm{H}, J_{5,6 \mathrm{a}} 5.8 \mathrm{~Hz}, J_{6 \mathrm{a}, 6 \mathrm{~b}} 8.9 \mathrm{~Hz}, \mathrm{H}-6 \mathrm{a}\right), 3.25,3.22,3.21$ (3s, each 3H, $2 \times$ OMe-1, OMe-5'), 1.42, 1.41, 1.37, $1.30\left(4 \mathrm{~s}\right.$, each $\left.3 \mathrm{H}, 2 \times \mathrm{CMe}_{2}\right) ;{ }^{13} \mathrm{C} \mathrm{NMR}\left(50 \mathrm{MHz}, \mathrm{CDCl}_{3}\right)$ : see Table 2 and $\delta 138.7,138.5$, 138.4, $137.2\left(4 \times\right.$ Ar-C), 128.1-127.1 (Ar-CH), 109.6, $108.3\left(2 \times C \mathrm{Me}_{2}\right), 74.8,74.5,73.1,72.6(4 \times$ $\left.\mathrm{CH}_{2} \mathrm{Ph}\right), 55.4,52.0(2 \times \mathrm{OMe}-1), 47.8(\mathrm{OMe}-5 '), 27.2,26.6,26.1,25.1\left(2 \times \mathrm{CMe}_{2}\right)$. Anal. Calcd for $\mathrm{C}_{49} \mathrm{H}_{62} \mathrm{O}_{13}: \mathrm{C}, 68.51 ; \mathrm{H}, 7.27$. Found: C, 68.63; H, 7.34.

\subsection{4. (5R)-2,4,6-Tri-O-benzyl-5- $C$-methoxy- $\alpha$-L-threo-hex-3-ulopyranosyl-( $1 \rightarrow 4)-2,3: 5,6-d i-O$ - isopropylidene-aldehydo-D-glucose dimethyl acetal (24)}

A suspension of $22(1.03 \mathrm{~g}, 1.34 \mathrm{mmol})$ in dry $\mathrm{CH}_{2} \mathrm{Cl}_{2}(27 \mathrm{~mL})$, pre-dried 4-methylmorpholine$\mathrm{N}$-oxide (NMO) (275 mg, $2.34 \mathrm{mmol})$ and $4 \AA$ powdered molecular sieves (400 mg) was stirred under argon atmosphere for $30 \mathrm{~min}$ at room temp. Tetrapropylammonium perruthenate (TPAP) (47 $\mathrm{mg}, 10 \%$ ) was added and the resulting green mixture was stirred for $4 \mathrm{~h}$ at room temp until the TLC (9:1 $\left.\mathrm{CH}_{2} \mathrm{Cl}_{2}-\mathrm{Me}_{2} \mathrm{CO}\right)$ showed the complete disappearance of the starting material. The reaction mixture was filtered through alternate paths of Celite and silica gel and extensively washed with $\mathrm{CH}_{2} \mathrm{Cl}_{2}$ and EtOAc. The soln and washings were combined and concentrated under diminished pressure to give almost pure 24 (NMR). A sample of the residue was subjected to flash chromatography $\left(7: 3\right.$ hexane-EtOAc) to give $24\left(76 \%\right.$ yield) as a colourless syrup; $[\alpha]_{\mathrm{D}}-37.4(c$ 1.16, $\left.\mathrm{CHCl}_{3}\right) ; R_{\mathrm{f}} 0.73\left(9: 1 \mathrm{CH}_{2} \mathrm{Cl}_{2}-\mathrm{Me}_{2} \mathrm{CO}\right) ;{ }^{1} \mathrm{H} \mathrm{NMR}\left(200 \mathrm{MHz}, \mathrm{CD}_{3} \mathrm{CN}\right)$ : see Table 1 and $\delta$ 7.38-7.13 (m, 15H, Ar-H), 4.70, 4.64 (AB system, 2H, $\left.J_{\mathrm{A}, \mathrm{B}} 12.5 \mathrm{~Hz}, \mathrm{CH}_{2} \mathrm{Ph}\right), 4.53,4.47(\mathrm{AB}$ system, 2H, $J_{\mathrm{A}, \mathrm{B}} 12.4 \mathrm{~Hz}, \mathrm{CH}_{2} \mathrm{Ph}$ ), 4.40-4.32 (m, 4H, H-1, H-2, $\mathrm{CH}_{2} \mathrm{Ph}$ ), 4.21 (m, 1H, H-5), 4.07 (dd, 1H, $\left.J_{5,6 \mathrm{~b}} 6.0 \mathrm{~Hz}, J_{6 \mathrm{a}, 6 \mathrm{~b}} 8.5 \mathrm{~Hz}, \mathrm{H}-6 \mathrm{~b}\right), 4.03$ (dd, 1H, J,3 $6.9 \mathrm{~Hz}, J_{3,4} 1.1 \mathrm{~Hz}, \mathrm{H}-3$ ), 3.93 (dd, 1H, $\left.J_{5,6 \mathrm{a}} 6.3 \mathrm{~Hz}, \mathrm{H}-6 \mathrm{a}\right), 3.87$ (dd, 1H, $\left.J_{4,5} 5.5 \mathrm{~Hz}, \mathrm{H}-4\right), 3.31,3.25,3.23$ (3s, each 3H, $2 \times$ OMe-1, OMe-5'), 1.34, 1.33, 1.32, 1.27 (4s, each $\left.3 \mathrm{H}, 2 \times \mathrm{CMe}_{2}\right) ;{ }^{13} \mathrm{C}$ NMR $\left(50 \mathrm{MHz}, \mathrm{CD}_{3} \mathrm{CN}\right)$ : see Table 2 and $\delta$ 138.8, 138.6, $137.8\left(3 \times\right.$ Ar-C), 129.3-128.8 (Ar-CH), 110.4, $109.2\left(2 \times C \mathrm{Me}_{2}\right), 74.0,73.9$, $73.0\left(3 \times \mathrm{CH}_{2} \mathrm{Ph}\right), 56.5,53.8\left(2 \times \mathrm{OMe}^{-1}\right), 49.1\left(\mathrm{OMe}-5{ }^{\prime}\right), 27.4,26.9,26.8,25.5\left(2 \times \mathrm{CMe}_{2}\right)$. Anal. Calcd for $\mathrm{C}_{42} \mathrm{H}_{54} \mathrm{O}_{13}$ : C, 65.78; H, 7.10. Found: C, 65.88; H, 7.38.

\subsection{5. (5R)-2,4,6-Tri- $O$-benzyl-5- $C$-methoxy- $\alpha$-L-lyxo-hexopyranosyl-(1 $\rightarrow 4)-2,3: 5,6-d i-O$ - isopropylidene-aldehydo-D-glucose dimethyl acetal (25)}

A soln of 24 (760 mg, $0.99 \mathrm{mmol})$ in dry $\mathrm{MeOH}(22 \mathrm{~mL})$ was cooled to $0{ }^{\circ} \mathrm{C}$ and treated, under argon atmosphere, with $\mathrm{NaBH}_{4}(113 \mathrm{mg}, 2.98 \mathrm{mmol})$. After 5 min the reaction mixture was gently warmed to room temp and left under stirring until 24 was consumed (1.5 h, TLC, 9:1 $\mathrm{CH}_{2} \mathrm{Cl}_{2}$ $\left.\mathrm{Me}_{2} \mathrm{CO}\right)$. Water $(15 \mathrm{~mL})$ was added, the soln stirred for $30 \mathrm{~min}$, concentrated under diminished 
pressure and the residue partitioned between water $(60 \mathrm{~mL})$ and $\mathrm{CH}_{2} \mathrm{Cl}_{2}(150 \mathrm{~mL})$. The aq phase was extracted with $\mathrm{CH}_{2} \mathrm{Cl}_{2}(2 \times 150 \mathrm{~mL})$, the organic extracts collected, dried $\left(\mathrm{MgSO}_{4}\right)$ and concentrated under diminished pressure. The residue $(784 \mathrm{mg})$ was subjected to flash chromatography (6:4 hexane-EtOAc) to give 25 as a colourless syrup (668 $\mathrm{mg}, 88 \%$ yield); $[\alpha]_{\mathrm{D}}$ $+2.20\left(\right.$ c $\left.0.7, \mathrm{CHCl}_{3}\right) ; R_{\mathrm{f}} 0.38\left(9: 1 \mathrm{CH}_{2} \mathrm{Cl}_{2}-\mathrm{Me}_{2} \mathrm{CO}\right) ;{ }^{1} \mathrm{H} \mathrm{NMR}\left(200 \mathrm{MHz}, \mathrm{CDCl}_{3}\right)$ : see Table 1 and $\delta$ 7.38-7.05 (m, 15H, Ar-H), 4.81, 4.63 (AB system, 2H, $\left.J_{\mathrm{A}, \mathrm{B}} 12.2 \mathrm{~Hz}, \mathrm{CH}_{2} \mathrm{Ph}\right), 4.58,4.36(\mathrm{AB}$ system, $\left.2 \mathrm{H}, J_{\mathrm{A}, \mathrm{B}} 12.1 \mathrm{~Hz}, \mathrm{CH}_{2} \mathrm{Ph}\right), 4.48\left(\mathrm{dd}, 1 \mathrm{H}, J_{1,2} 6.7 \mathrm{~Hz}, J_{2,3} 7.6 \mathrm{~Hz}, \mathrm{H}-2\right), 4.47,4.39$ (AB system, 2H, $\left.J_{\mathrm{A}, \mathrm{B}} 11.4 \mathrm{~Hz}, \mathrm{CH}_{2} \mathrm{Ph}\right), 4.31$ (d, 1H, H-1), 4.24 (m, 1H, H-5), 4.03 (dd, 1H, J3,4 $1.0 \mathrm{~Hz}$, H-3), 4.00 (m, 2H, H-6a, H-6b), 3.88 (dd, 1H, J4,5 5.2 Hz, H-4), 3.28, 3.25, 3.15 (3s, each 3H, $2 \times$ OMe-1, OMe-5'), 1.44, 1.43, 1.42, 1.33 (4s, each 3H, $\left.2 \times \mathrm{CMe}_{2}\right) ;{ }^{13} \mathrm{C} \mathrm{NMR}\left(50 \mathrm{MHz}, \mathrm{CDCl}_{3}\right)$ : see Table 2 and $\delta 138.9,138.3,138.1$ (3 $\times$ Ar-C), 128.9-128.3 (Ar-CH), 110.5, $109.2\left(2 \times C \mathrm{Me}_{2}\right), 73.9$, 73.7, $73.2\left(3 \times \mathrm{CH}_{2} \mathrm{Ph}\right), 56.5,53.4(2 \times \mathrm{OMe}-1), 48.9\left(\mathrm{OMe}-5{ }^{\prime}\right), 27.9,27.2,27.1,26.0\left(2 \times \mathrm{CMe}_{2}\right)$. Anal. Calcd for $\mathrm{C}_{42} \mathrm{H}_{56} \mathrm{O}_{13}$ : C, 65.61; H, 7.34. Found: C, 65.68; H, 7.41.

\subsection{2,4,6-Tri-O-benzyl-L-lyxo-hexos-5-ulose (27)}

A soln of 25 (456 mg, $0.594 \mathrm{mmol})$ in $4: 1(\mathrm{v} / \mathrm{v}) \mathrm{CH}_{3} \mathrm{CN}$-water $(11 \mathrm{~mL})$ was treated with $90 \%$ aq $\mathrm{CF}_{3} \mathrm{COOH}\left(2.3 \mathrm{~mL}\right.$ ) warmed to $50{ }^{\circ} \mathrm{C}$ and stirred until the TLC analysis (EtOAc) showed the complete disappearance of the starting material $(4 \mathrm{~h})$. The mixture was concentrated under diminished pressure and repeatedly co-evaporated with toluene $(5 \times 20 \mathrm{~mL})$. The residue was partitioned between brine $(20 \mathrm{~mL})$ and EtOAc $(40 \mathrm{~mL})$ and the aq phase extracted with EtOAc $(3 \times$ $40 \mathrm{~mL})$. The organic phases were collected, dried $\left(\mathrm{MgSO}_{4}\right)$, concentrated under diminished pressure to give a residue $(285 \mathrm{mg})$, that was directly subjected to a flash chromatographic purification, eluting with 4:6 hexane-EtOAc, to give 27 (228 mg, 86\% yield) as a colourless syrup. NMR data were in agreement with those of the sample previously prepared by us. ${ }^{6 b}$

\section{Acknowledgement}

This research was partly supported by Ministero dell'Università e della Ricerca (MIUR, Rome, Italy) in the frame of the COFIN national project.

\section{References}

1. Guazzelli, L.; Catelani, G.; D’Andrea, F.; Giannarelli, A. Carbohydr. Res. 2008,, doi :10.1016/j.carres.2008.11.018.

2. (a) Schaafsma, G. International Dairy Journal 2008, 18, 458-465; (b) Various Authors in Carbohydrates in Europe 1999, 25, 13-37. 
3. Barili, P. L.; Catelani, G.; D’Andrea, F.; De Rensis, F.; Falcini P. Carbohydr. Res. 1997, 298, $75-84$

4. (a) Theander, O. Acids and other oxidation products. In The Carbohydrates, Chemistry and Biochemistry, $2^{\text {nd }}$ ed.; Pigman, W., Horton, D., Eds.; Academic Press: New York, 1980; Vol. IB, pp 1013-1099; (b) De Lederkremer, R. M.; Marino, C. Adv. Carbohydr. Chem. Biochem. 2003, $58,199-306$.

5. (a) Baxter, E. W.; Reitz, A. B. J. Org. Chem. 1994, 59, 3175-3185; (b) Barili, P. L.; Berti, G.; Catelani, G.; D’Andrea, F.; De Rensis, F.; Puccioni, L. Tetrahedron 1997, 53, 3407-3416.

6. (a) Pistarà, V.; Barili, P. L.; Catelani, G.; Corsaro, A.; D’Andrea, F.; Fisichella, S. Tetrahedron Lett. 2000, 41, 3253-3256; (b) Catelani, G.; Corsaro, A.; D’Andrea, F.; Mariani, M.; Pistarà, V. Bioorg. Med. Chem. Lett. 2002, 12, 3313-3315.

7. Adinolfi, M.; Barone, G.; Iadonisi, A.; Mangoni, L. Tetrahedron Lett. 1998, 39, 2021-2024.

8. (a) (for L-arabino): Barili, P. L.; Berti, G.; Catelani, G.; D’Andrea, F. Gazz. Chim. Ital. 1992, 122, 135-142; (b) (for D-xylo): Barili, P. L.; Berti, G.; Catelani, G.; D’Andrea, F.; De Rensis, F. Tetrahedron 1997, 53, 8665-8674; (c) (for L-lyxo): Barili, P. L.; Catelani, G.; D’Andrea, F.; De Rensis, F.; Goracci G. J. Carbohydr. Chem. 1998, 17, 1167-1180; (d) (for L-ribo): Barili, P. L.; Bergonzi, M. C.; Berti, G.; Catelani, G.; D’Andrea, F.; De Rensis, F. J. Carbohydr. Chem. 1999, 18, 1037-1049.

9. (a) Catelani, G.; Corsaro, A.; D’Andrea, F.; Mariani, M.; Pistarà, V.; Vittorino, E. Carbohydr. Res. 2003, 338, 2349-2358; (b) Corsaro, A.; Catelani, G.; D’Andrea, F.; Fisichella, S.; Mariani, M.; Pistarà, V. Environ. Sci. \& Pollut. Res. 2003, 10, 325-328.

10. David, S.; Hanessian, S. Tetrahedron 1985, 41, 643-663.

11. (a) with $\mathrm{Bu}_{4} \mathrm{NCN}$ : Ren, Z.-X.; Yang, Q.; Price, K. N.; Chen, T.; Nygren, C.; Turner, J. F. C.; Baker, D. C. Carbohydr. Res. 2007, 342, 1668-1679; (b) with KI: Lin, T.-H.; Kováč, P.; Glaudemans, C. P. J. Carbohydr. Res. 1989, 188, 228-238; (c) with pyridine: El Nemr, A.; Tsuchiya, T. Carbohydr. Res. 2001, 330, 205-214.

12. Ley, S. V.; Griffith, W. P.; Norman, J.; Marsden, S. P. Synthesis 1994, 639-666.

13. Chang, C.-W. T.; Hui, Y.; Elchert, B. Tetrahedron Lett. 2001, 42, 7019-7023.

14. Bernet, B.; Vasella, A. Helv. Chim. Acta 2000, 83, 995-1021.

15. Flowers, H. M. Carbohydr. Res. 1975, 39, 245-251.

16. Attolino, E.; Bonaccorsi, F.; Catelani, G.; D’Andrea, F. Carbohydr. Res. 2008, 343, 2545-2556. 
Table 1: ${ }^{1} \mathrm{H}$ NMR parameters $(\delta, \mathrm{ppm} ; J, \mathrm{~Hz})$ of the non-reducing unit of 9-11, 14, 16-20 and 22-25

\begin{tabular}{cccccccccccc} 
Compound & Solvent & $\mathrm{H}-1^{\prime}$ & $\mathrm{H}-2^{\prime}$ & $\mathrm{H}-3^{\prime}$ & $\mathrm{H}-4^{\prime}$ & $\mathrm{H}-6{ }^{\prime} \mathrm{a}$ & $\mathrm{H}-66^{\prime} \mathrm{b}$ & $J_{1^{\prime}, 2^{\prime}}$ & $J_{2^{\prime}, 3^{\prime}}$ & $J_{3^{\prime} 4^{\prime}}$ & $J_{6^{\prime} \mathrm{a}, 6^{\prime} \mathrm{b}}$ \\
\hline $\mathbf{9}$ & $\mathrm{CDCl}_{3}$ & 4.86 & 3.61 & 3.89 & 4.11 & 3.59 & 3.50 & 7.9 & 9.4 & 3.7 & 10.4 \\
$\mathbf{1 0}$ & $\mathrm{CD}_{3} \mathrm{CN}$ & 4.92 & 3.51 & 4.02 & 5.33 & 3.70 & 3.38 & 7.9 & 9.8 & 2.4 & 11.0 \\
$\mathbf{1 1}$ & $\mathrm{CD}_{3} \mathrm{CN}$ & 5.15 & 3.91 & -- & 5.06 & 3.65 & 3.31 & 6.2 & -- & -- & 10.2 \\
$\mathbf{1 4}$ & $\mathrm{CD}_{3} \mathrm{CN}$ & 4.86 & 3.38 & 3.60 & 3.79 & 3.72 & 3.58 & 8.0 & 9.1 & 9.1 & 10.1 \\
$\mathbf{1 6}$ & $\mathrm{CDCl}_{3}$ & 4.93 & 3.42 & 3.97 & 5.41 & 3.42 & 3.25 & 7.9 & 10.0 & 3.4 & 10.8 \\
$\mathbf{1 7}$ & $\mathrm{CDCl}_{3}$ & 5.04 & 4.04 & -- & 5.09 & 3.57 & 3.34 & 7.3 & -- & -- & 10.6 \\
$\mathbf{1 8}$ & $\mathrm{CDCl}_{3}$ & 5.24 & 3.45 & 3.45 & 5.10 & 3.33 & 3.27 & 8.2 & 3.3 & n.d. & 10.3 \\
$\mathbf{1 9}$ & $\mathrm{CDCl}_{3}$ & 5.31 & 3.63 & 5.24 & 3.42 & 3.52 & 3.46 & 8.2 & 3.6 & 3.3 & 10.6 \\
$\mathbf{2 0}$ & $\mathrm{CDCl}_{3}$ & 5.31 & 3.42 & 5.21 & 5.08 & 3.42 & 3.24 & 8.3 & 3.4 & 3.0 & 10.5 \\
$\mathbf{2 2}$ & $\mathrm{CDCl}_{3}$ & 4.86 & 3.52 & 4.00 & 3.87 & 3.53 & 3.45 & 7.9 & 9.9 & 3.4 & 10.3 \\
$\mathbf{2 3}$ & $\mathrm{CDCl}_{3}$ & 4.82 & 3.82 & 3.82 & 4.05 & 3.57 & 3.41 & 7.6 & n.d. & n.d. & 10.1 \\
$\mathbf{2 4}$ & $\mathrm{CD}_{3} \mathrm{CN}^{2 \mathbf{n}}$ & 4.91 & 4.31 & -- & 3.74 & 3.61 & 3.55 & 7.5 & -- & -- & 10.6 \\
$\mathbf{2 5}$ & $\mathrm{CDCl}_{3}$ & 5.17 & 3.51 & 3.99 & 3.73 & 3.55 & 3.42 & 8.4 & 3.4 & 3.2 & 10.2 \\
\hline
\end{tabular}


Table 2: Selected ${ }^{13} \mathrm{C}$ NMR signals $(\delta$, ppm) of the disaccharide derivatives 9-11, 14 and 16-25.

\begin{tabular}{|c|c|c|c|c|c|c|c|c|c|c|c|c|c|}
\hline Compound & Solvent & $\mathrm{C}-1$ & $\mathrm{C}-2$ & $\mathrm{C}-3$ & C-4 & $C-5$ & C-6 & $\mathrm{C}-1^{\prime}$ & $\mathrm{C}-2^{\prime}$ & C-3' & C-4' & C-5' & C-6' \\
\hline 9 & $\mathrm{CDCl}_{3}$ & 105.5 & 74.4 & 77.8 & 75.0 & 77.2 & 65.5 & 98.9 & 78.8 & 78.6 & 67.2 & 100.3 & 64.7 \\
\hline 10 & $\mathrm{CD}_{3} \mathrm{CN}$ & 106.4 & 75.7 & 76.6 & 76.5 & 77.7 & 66.1 & 100.3 & 79.2 & 78.3 & 82.7 & 99.8 & 65.3 \\
\hline 11 & $\mathrm{CD}_{3} \mathrm{CN}$ & 106.6 & 76.0 & 78.8 & 76.5 & 77.9 & 66.2 & 99.6 & 76.5 & 155.3 & 99.4 & 99.5 & 70.3 \\
\hline 14 & $\mathrm{CD}_{3} \mathrm{CN}$ & 106.9 & 76.2 & 78.4 & 76.9 & 77.8 & 66.2 & 99.7 & $82.8^{*}$ & $82.0^{\mathrm{a}^{*}}$ & 74.1 & 99.9 & 74.4 \\
\hline 16 & $\mathrm{CDCl}_{3}$ & 105.5 & $74.5^{*}$ & $77.8^{*}$ & 76.4 & $77.6^{*}$ & 64.8 & 98.4 & $74.3^{*}$ & $69.6^{*}$ & $68.8^{*}$ & 99.5 & 64.1 \\
\hline 17 & $\mathrm{CDCl}_{3}$ & 106.1 & $75.0^{*}$ & 77.6 & $75.1^{*}$ & 76.9 & 65.3 & 100.0 & 80.2 & 197.2 & $74.9^{*}$ & 99.9 & 64.2 \\
\hline 18 & $\mathrm{CDCl}_{3}$ & 106.2 & 75.5 & 77.7 & 75.2 & 77.3 & 65.4 & 96.4 & 74.3 & $69.3^{*}$ & $69.2^{*}$ & 101.6 & 64.9 \\
\hline 19 & $\mathrm{CDCl}_{3}$ & 105.6 & $74.8^{*}$ & 78.0 & $74.7^{*}$ & 77.7 & 65.3 & 96.2 & $73.8^{*}$ & 71.6 & 68.4 & 101.4 & 66.2 \\
\hline 20 & $\mathrm{CDCl}_{3}$ & 105.8 & 74.8 & $77.9^{*}$ & 75.1 & $77.8^{*}$ & 65.2 & 95.9 & 73.1 & $68.5^{*}$ & $68.4^{*}$ & 100.5 & 65.2 \\
\hline 21 & $\mathrm{CDCl}_{3}$ & 105.9 & 74.7 & 77.8 & 75.4 & 77.5 & 65.4 & 96.1 & 74.7 & 71.6 & 69.6 & 102.3 & 65.9 \\
\hline 22 & $\mathrm{CDCl}_{3}$ & 105.4 & 74.3 & 77.8 & 74.6 & 77.3 & 65.2 & 99.1 & 79.6 & 70.7 & 77.5 & 100.8 & 64.7 \\
\hline 23 & $\mathrm{CDCl}_{3}$ & 105.2 & 74.0 & 77.6 & 74.8 & 76.9 & 65.4 & 99.1 & 79.4 & 79.2 & 75.1 & 100.6 & 64.5 \\
\hline 24 & $\mathrm{CD}_{3} \mathrm{CN}$ & 106.5 & 75.8 & 78.4 & 77.4 & 77.7 & 66.2 & 100.9 & 82.0 & 202.3 & 82.0 & 101.6 & 64.9 \\
\hline 25 & $\mathrm{CDCl}_{3}$ & 106.4 & 74.9 & 77.9 & 75.2 & 76.3 & 65.7 & 97.3 & $78.5^{*}$ & 70.1 & $78.3^{*}$ & 103.5 & 66.2 \\
\hline
\end{tabular}

\footnotetext{
* Assignments may have to be interchanged
} 